\title{
SELEÇÃO DE LINHAGENS DE GALINHAS PARA CORTE ADAPTADAS AO SISTEMA DE CRIAÇÃO SEMI-INTENSIVO
}

\author{
Marco Aurélio Neves Da Silva \\ Engenheiro Agrônomo
}

Orientador: Prof. Dr. ANTONIO AUGUSTO DOMINGOS COELHO

Dissertação apresentada à Escola Superior de Agricultura "Luiz de Queiroz", Universidade de São Paulo, para obtenção do título de Mestre em Agronomia, Área de Concentração: Genética e Melhoramento de Plantas.

P I R A C I C A B A

Estado de São Paulo - Brasil

Novembro -2001 
SILVA, M.A.N. Seleção de linhagens de galinhas para corte adaptadas ao sistema de criação semi-intensivo. Piracicaba, 2001. 54p. Dissertação (Mestrado) - Universidade de São Paulo.

\section{ERRATA}

\begin{tabular}{|c|c|c|c|}
\hline Página & Linha & Onde se lê ... & Leia-se ... \\
\hline viii & 4 & $\ldots$ esse sistema ... & $\ldots$ esses sistemas ... \\
\hline ix & 6 & ... research developing ... & $\ldots$ the development of researches ... \\
\hline Ix & 9 & $\ldots$ fenotypical ... & ... phenotypical ... \\
\hline 6 & 7 & ... four repetition. & ... four replications \\
\hline 6 & 7 & $\begin{array}{l}\text {... being each block made of } \\
\text { four ... }\end{array}$ & ... each block composed by four ... \\
\hline 6 & 8 & $\ldots$ days od during $\ldots$ & $\ldots$ days old, during $\ldots$ \\
\hline 6 & 9 & $\ldots$ data of number ... & $\ldots$ data of the number ... \\
\hline 6 & 10 & $\ldots$ areas and porcentage ... & $\ldots$ areas, and porcentage $\ldots$ \\
\hline 8 & 13 & ... já que por meios ... & ... já que por meio ... \\
\hline 11 & 18 & $\ldots$ temperatura no pasto ... & ... temperatura de globo negro no pasto ... \\
\hline 18 & 9 & $\ldots$ in the ages . & $\ldots$ at the ages $\ldots$ \\
\hline 18 & 14 & $\begin{array}{l}\ldots \text { welfare having positively } \\
\text { influenced physiological ... }\end{array}$ & $\begin{array}{l}\text {... welfare, influencing positively } \\
\text { physiological ... }\end{array}$ \\
\hline 28 & 18 & ... fenotypical ... & ... phenotypical ... \\
\hline 29 & 2 & $\ldots 7 \mathrm{P}$ and two $\ldots$ & $\ldots 7 \mathrm{P}$, and two $\ldots$ \\
\hline 29 & 3 & ... presented ... & $\ldots$ showed ... \\
\hline 29 & 3 & $\ldots$ higher with $7 \mathrm{P} \ldots$ & $\ldots$ higher than $7 \mathrm{P} \ldots$ \\
\hline 29 & 3 & ... ower with $\mathrm{C} 1 \ldots$ & ... lower than $\mathrm{C} 1 \ldots$ \\
\hline 29 & 3 & $\ldots$ the group analysis ... & $\ldots$ the grouping analysis ... \\
\hline
\end{tabular}

\begin{tabular}{|c|c|c|c|}
\hline Página & Tabela & Onde se lê & Leia-se \\
\hline 36 & 8 & Pirmer 1 & Primer 1 e 2 \\
\hline 36 & 8 & Primer 1 e 2 & Primer 1 \\
\hline \multirow[t]{5}{*}{36} & 8 & Primer 1 a 7 & Primer 1 a 7 \\
\hline & & 1,000 & 1,000 \\
\hline & & $0,897 \quad 1,000$ & $0,911 \quad 1,000$ \\
\hline & & $\begin{array}{llll}0,800 & 0,878 & 1,000\end{array}$ & $\begin{array}{llll}0,826 & 0,894 & 1,000\end{array}$ \\
\hline & & $\begin{array}{llll}0,916 & 0,872 \quad 0,925 & 1,00 \backslash 0\end{array}$ & $\begin{array}{llll}0,931 & 0,879 & 0,925 & 1,000\end{array}$ \\
\hline
\end{tabular}




\section{Dados Internacionais de Catalogação na Publicação (CIP) DIVISÃO DE BIBLIOTECA E DOCUMENTAÇÃO - ESALQ/USP}

Silva, Marco Aurélio Neves da

Seleção de linhagens de galinhas para corte adaptadas ao sistema de criação semiintensivo / Marco Aurélio Neves da Silva. - - Piracicaba, 2001.

$54 \mathrm{p}$.

Dissertação (mestrado) - Escola Superior de Agricultura Luiz de Queiroz, 2001. Bibliografia.

1. Desempenho animal 2. Galinha de corte 3. Linhagem animal 4. Melhoramento genético animal 5. Seleção genética 6 . Técnica molecular 1 . Título

CDD 636.513

"Permitida a copia total ou parcial deste documento, desde que citada a fonte - O autor" 
À minha família e amigos,

pelo amor, compreensão,

paciência e incentivo,

\section{DEDICO}




\section{AGRADECIMENTOS}

- Aos Professores Dr. Antonio Augusto Domingos Coelho e Dr. Vicente José Maria Savino, pela amizade e orientação na execução deste trabalho.

- Ao Professor Dr. Paulo Hellmeister Filho, pela colaboração no planejamento e execução deste trabalho.

- Ao Amigo Edmilson Martins, pelos risos nas horas boas e apoio nas horas difíceis.

- Ao Bolsista Millor Fernandes do Rosário, pela colaboração antes e depois da execução deste trabalho.

- Ao Professor Dr. Iran José Oliveira da Silva, pela colaboração na elaboração deste trabalho.

- Ao Professor Dr. José Fernando Machado Menten, pelo incentivo na elaboração deste trabalho.

- Ao Dr. Luiz Humberto Gomes pelo apoio na execução das análises laboratoriais.

- Ao Professor Dr. Antonio Augusto Franco Garcia pelo assessoramento nas análises estatísticas. 
- Ao Dr. Mateus Mondin pela eterna amizade.

- Aos Funcionários do Setor de Aves do Departamento de Genética e do Departamento de Produção Animal, pela indispensável colaboração na condução do experimento e coleta de dados.

- Aos Professores da Escola Superior de Agricultura "Luiz de Queiroz" que contribuíram para minha formação acadêmica.

- À CAPES pela concessão de bolsa de estudos.

- A todos que direta ou indiretamente contribuíram para a execução deste trabalho. 


\section{SUMÁRIO}

Página

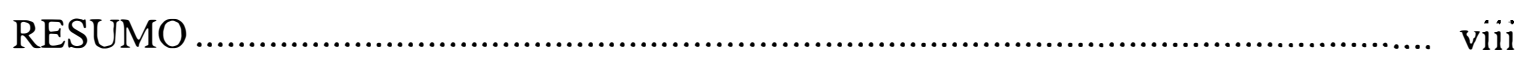

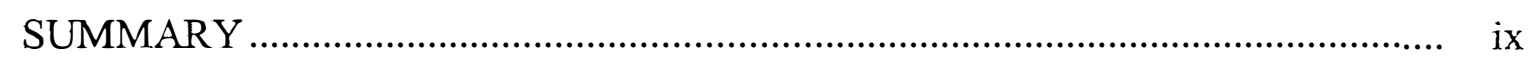

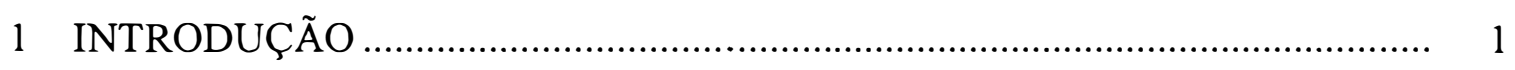

2 REVISÃO DE LITERATURA ..................................................................... 3

3 ANÁLISE BIOCLIMÁTICA E DO COMPORTAMENTO NO ESTUDO

DA ADAPTAÇÃO DE GALINHAS PARA CORTE AO SISTEMA DE CRIAÇÃO SEMI-INTENSIVO...................................................................... 5

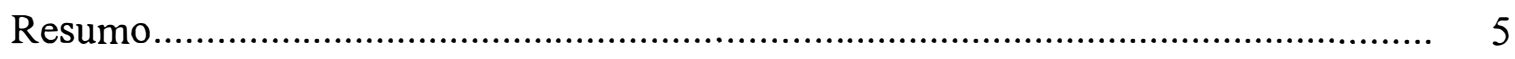

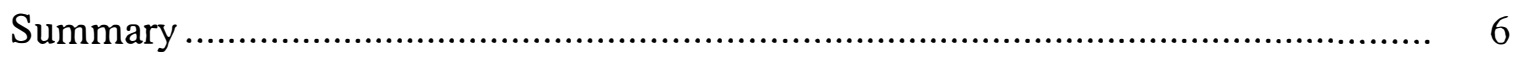

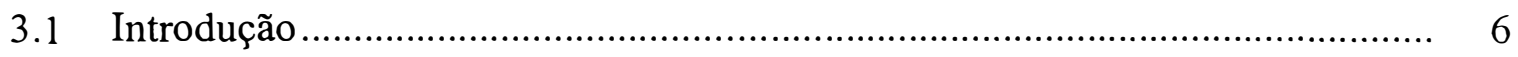

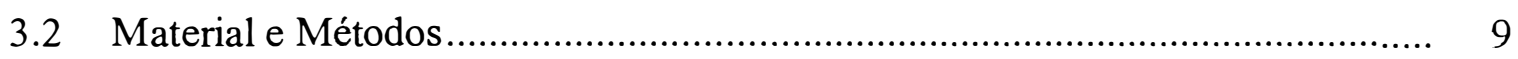

3.3 Resultados e Discussão ............................................................................ 11

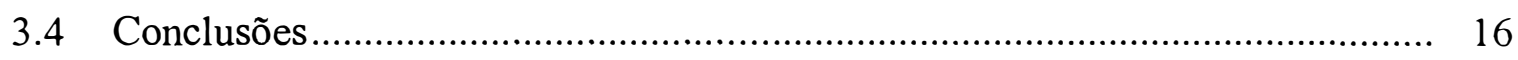

4 INFLUÊNCIA DO SISTEMA DE CRIAÇÃO SOBRE

CARACTERÍSTICAS FISIOLÓGICAS E PESO CORPORAL DE

LINHAGENS DE GALINHAS PARA CORTE ……........................................ 17

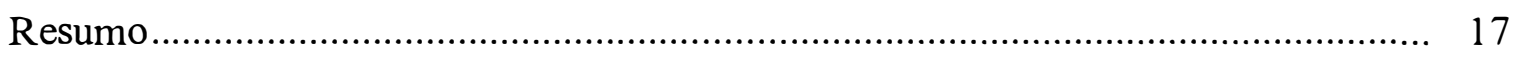

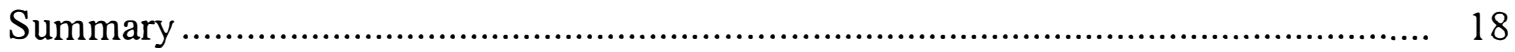

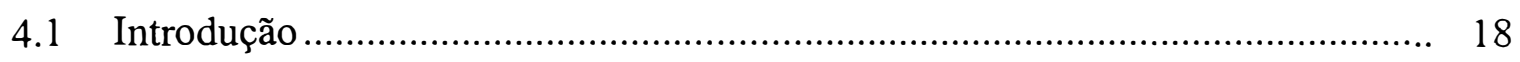

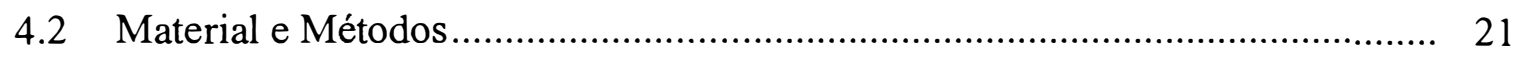

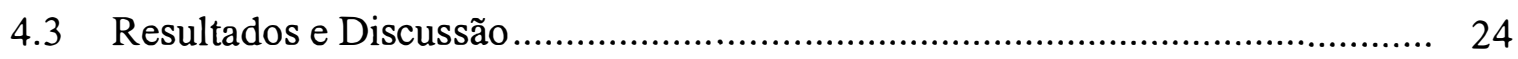

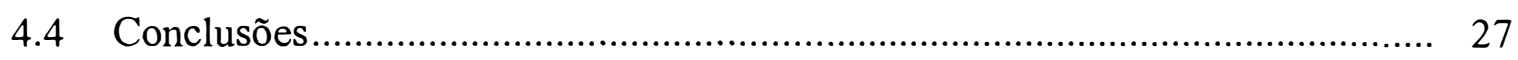


5 CARACTERIZAÇÃO MOLECULAR DE LINHAGENS DE GALINHAS PARA CORTE CRIADAS EM SISTEMA SEMI-INTENSIVO …......................... 28

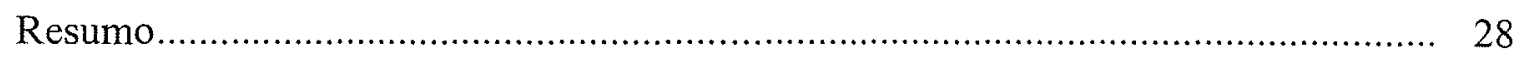

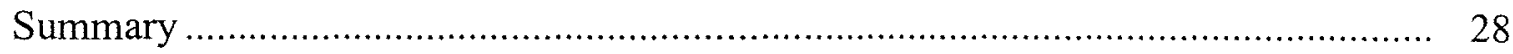

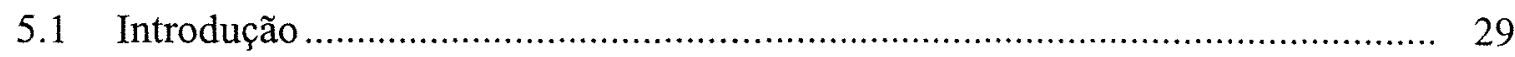

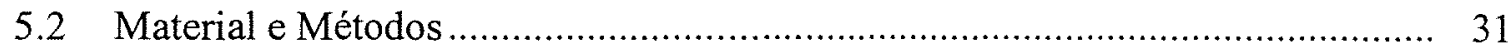

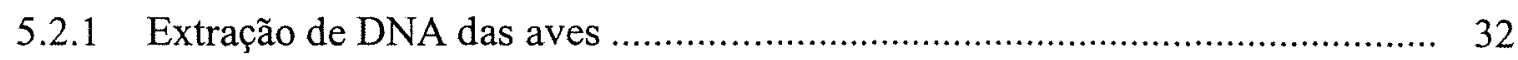

5.2.2 Quantificação do DNA extraído ............................................................. 33

5.2.3 Amplificação do DNA …….................................................................... 34

5.2.4 Eletroforese do produto da amplificação …….............................................. 34

5.3 Resultados e Discussão ........................................................................... 35

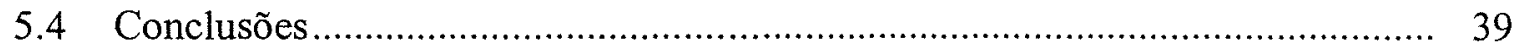

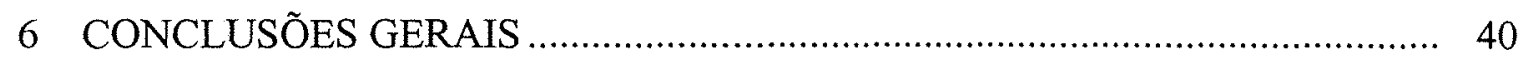

REFERÊNCIAS BIBLIOGRÁFICAS................................................................ 41

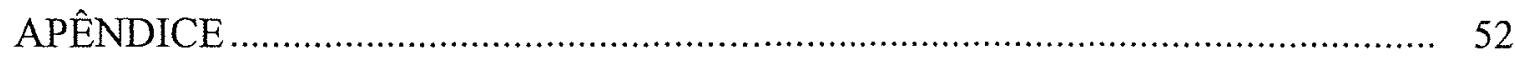




\title{
SELEÇÃO DE LINHAGENS DE GALINHAS PARA CORTE ADAPTADAS AO SISTEMA DE CRIAÇÃO SEMI-INTENSIVO
}

\author{
Autor: Marco Aurélio Neves da Silva \\ Orientador: Dr. Antonio Augusto Domingos Coelho
}

\section{RESUMO}

$\mathrm{O}$ atendimento de novas tendências do mercado consumidor, que deseja um produto final diferenciado e de qualidade superior, requer mudanças na cadeia produtiva da avicultura. É necessária a utilização de sistemas alternativos de criação, bem como o emprego de aves especializadas e adaptadas a esse sistema.. O crescente interesse na criação semi-intensiva, que minimiza fatores estressantes para o comportamento e bem-estar das aves, bem como, na utilização de linhagens especializadas e adaptadas a esse sistema, vem estimulando a realização de pesquisas. Neste sentido, pretendeu-se com a execução deste projeto, obter informações detalhadas sobre o desempenho e adaptabilidade de linhagens especializadas de galinhas para corte, a esse sistema de produção. Técnicas moleculares e critérios fenotípicos que permitem a seleção de materiais genéticos foram empregados, com o intuito de aumentar a produtividade e rentabilidade da avicultura alternativa. 


\title{
SELECTION OF MEAT-TYPE CHICKEN LINES ADAPTED TO SEMI-INTENSIVE BREEDING SYSTEM
}

\author{
Author: Marco Aurélio Neves da Silva \\ Adviser: Dr. Antonio Augusto Domingos Coelho
}

\section{SUMMARY}

The demand of new tendencies in the consuming market that wishes a high quality final product requires changes in the production line of poultry. The use of alternative breeding systems is necessary, as well as the use of specialized poultry lines adapted to this system. The increasing interest on semi-intensive breeding, which minimizes stressing factors to the poultry behaviour and welfare, as well as the use of specialized lines adapted to this system has stimulated research developing. Therefore, it was planned in this project to obtain detailed information on the performance and adaptability of specialized meat-type chicken lines in this production system. Molecular techniques and fenotypical criteria, which allow the selection of genetic material, have been used in order to increase productivity and profitability of the alternative poultry production. 


\section{INTRODUÇÃo}

A avicultura de corte é uma atividade zootécnica que tem evoluído muito nos últimos trinta anos. Neste período a carne de frango ganhou espaço na preferência dos consumidores, provocando a necessidade de aumento na produção. No panorama atual, torna-se necessário elevar a eficiência da criação de frangos para corte, visando um menor custo de produção aliado ao bem-estar dos animais e a melhora na qualidade da carne, buscando garantir a satisfação dos consumidores.

O sistema de criação intensiva de frangos de corte, em regime de total confinamento até a idade de abate, vem sendo amplamente utilizado pelos produtores, pois, aliado a outros fatores, proporcionou o aumento da produção e eficiência da atividade. Recentemente porém, alguns produtores vêm procurando desenvolver a criação dessas aves em sistemas alternativos, informalmente conhecidos como "sistemas caipiras". Os objetivos destes criadores são diminuir os custos de produção e utilizar um sistema de criação mais natural uma vez que, a procura dos consumidores por produtos alternativos e de melhor qualidade, tem crescido bruscamente nos últimos anos. Esses produtores postulam também que outro fator relevante do "sistema caipira" é que pode ocorrer a melhora dos índices zootécnicos da criação, já que as aves não sofrem as pressões do ambiente, como ocorre quando são criadas em sistemas com altas densidades populacionais e em que permanecem confinadas durante todo o período de criação.

No entanto, para que ocorra o aumento da produtividade do sistema semiintensivo, tornando-se atrativo para os produtores, não basta o oferecimento de 
condições ambientais adequadas para os animais, é necessária também, a utilização de aves com alto potencial genético e adaptadas a esse sistema de criação.

Sendo assim, a avaliação e desenvolvimento de materiais genéticos especializados para o sistema semi-intensivo são de extrema importância. O emprego de metodologias clássicas do melhoramento genético para seleção e melhoria de características economicamente importantes dessas aves, aliado à seleção assistida por marcadores moleculares poderá proporcionar excelentes resultados em curto espaço de tempo.

Neste sentido, realizou-se a presente pesquisa com os objetivos de:

a) Analisar o desempenho zootécnico e a adaptabilidade ao sistema semi-intensivo de linhagens experimentais e comerciais de galinhas para corte, visando a seleção de características associadas ao bem-estar animal;

b) Caracterizar as linhagens selecionadas para o sistema de criação semi-intensivo através de marcadores moleculares. 


\section{REVISÃO DE LITERATURA}

O sistema de criação intensiva de frangos de corte, em que a ave permanece confinada em galpões, utilizado pela maioria dos criadores, exerce grande influência negativa, proporcionando condições adversas para o desenvolvimento dos animais (Ciocca et al., 1995 e Hall, 2001). Para evitar esse problema, Appleby et al. (1992) indicam a utilização de sistemas de criação alternativos, como por exemplo o sistema semi-intensivo, visando o bem-estar dos animais.

A indústria avícola tem como objetivos principais o aumento do potencial genético dos animais e a obtenção de produtos de qualidade a custos mínimos, em determinado sistema de produção (Preisinger, 1998). É essencial portanto, que o criador opte por sistemas que não afetem negativamente a produção mas que considerem o conforto e bem-estar animal (Moreng \& Avens, 1990).

Muir \& Craig (1998) e Preisinger (1998) consideram que aspectos ligados ao bem-estar do animal estão se tornando importantes para os produtores. De acordo com Broom (1991) pode-se definir bem-estar como sendo o estado do indivíduo em relação ao ambiente que o rodeia. Portanto, ao utilizar um sistema de criação em que os animais não sofrem tanto com as condições adversas do ambiente, o criador além de se beneficiar em termos produtivos, com a diminuição do estresse dos animais, também estará atuando para a melhoria do bem-estar dos mesmos (Von Borell, 1999).

O sistema de criação semi-intensivo tem permitido aos produtores a obtenção de um produto final diferenciado, de qualidade superior, que vem ganhando 
espaço e conquistando os consumidores (Gessulli, 1999). Além de representar uma atividade lucrativa, a avicultura alternativa surge como solução para os problemas econômicos dos pequenos produtores. Os produtores do setor de avicultura alternativa, dita "ecologicamente correta", que considera o bem-estar animal e a qualidade do produto final, estimulados por tendências naturalistas, vêm aumentando seu potencial de produção adotando projetos de criação mais eficientes (Ciocca, 1995).

Sendo assim, para que ocorra a satisfação das "novas necessidades" dos consumidores, são requeridas mudanças em toda a cadeia produtiva da avicultura, melhorando-se o sistema de criação e os animais a serem criados nesse sistema (Blokhuis et al., 2000 e Vercoe et al., 2000). A "avicultura alternativa" surge então como solução, já que os consumidores terão a sua disposição produtos de qualidade e os produtores podem entrar em um novo nicho de mercado ainda pouco explorado, mas com grandes perspectivas. 


\section{ANÁlISE BIOCLIMÁTICA E DO COMPORTAMENTO NO ESTUDO DA ADAPTAÇÃo de GAlinhas PARA CORTE AO SISTEMA DE CRIAÇÃo SEMI-INTENSIVO}

\section{Resumo}

A utilização do sistema semi-intensivo de criação, que minimiza fatores estressantes para o comportamento e bem-estar das aves, assim como a utilização de linhagens especializadas e adaptadas a esse sistema, podem resultar em maior produtividade e rentabilidade da avicultura alternativa. O objetivo deste trabalho foi avaliar a adaptação de linhagens de galinhas para corte ao sistema semi-intensivo de criação, através de parâmetros ambientais e comportamentais. O delineamento experimental foi em blocos casualizados, com quatro repetições, sendo cada bloco composto por quatro boxes, um para cada linhagem. O periodo de monitoramento desenvolveu-se entre 35 e 75 dias de idade, durante o qual foram coletados dados da quantidade de aves presentes no pasto, da temperatura e umidade relativa dos boxes e do pasto, e da porcentagem de sombra no pasto. Os parâmetros ambientais influenciaram o comportamento das linhagens avaliadas. A análise bioclimática e a observação do comportamento das aves permitiram diferenciar as linhagens estudadas, no que diz respeito à adaptação ao sistema semi-intensivo de criação. Três das linhagens avaliadas demonstraram o comportamento esperado para esse sistema, com o que se pode concluir terem sido proporcionadas condições de conforto e bem-estar adequadas. 


\section{Summary}

The use of semi-intensive breeding system, which minimizes stressing factors to the poultry behaviour and welfare, as well as the use of specialized lines adapted to this system may result in higher productivity and profitability of the alternative poultry production. The objective of this research was to evaluate the adaptation of the meat-type chicken lines to the semi-intensive breeding system through environmental and behavioural parameters. The experimental procedure was carried out in randomized blocks with four repetitions, being each block made of four boxes, one for each line. The monitoring period took place between 35 and 75 days old during which it was collected data of number of broilers in the pasture, air temperature and relative humidity inside the boxes and in the pasture areas and percentage of shadow in the pasture areas. Environmental factors influenced the behaviour of the evaluated lines. The bioclimatic analysis and the observation of the chicken behaviour allowed to discriminate the studied lines regarding the adaptation to the semi-intensive breeding system. Three of the evaluated lines presented the expected behaviour for this system what leads to the conclusion that adequate conditions of comfort and welfare have been provided.

\subsection{Introdução}

A grande procura dos consumidores por produtos diferenciados e de qualidade superior, vem influenciando mudanças nos sistemas utilizados pelos produtores para criação de frangos (Gessulli, 1999 e Vercoe et al., 2000). A sociedade está interessada em padrões para aumentar o bem-estar na criação de animais (Verbeke et al., 2000 e Von Borell \& Van den Weghe, 1999) e a implementação de mudanças que melhorem o bem-estar do animal pode garantir a aceitação pelos consumidores (Blokhuis et al., 2000 e Fraser, 2001). 
O confinamento causa estresse intenso (Jones \& Mills, 1999), tendo como conseqüência respostas fisiológicas e comportamentais (Abeyesinghe et al., 2001; Blokhuis et al., 1998; Dawkins, 1999; Hall, 2001 e Marin et al., 2001), podendo causar sérios problemas de saúde, produtividade e no bem-estar (Abeyesinghe et al., 2001; Hall, 2001 e Mendl, 1999). Por esses motivos, o sistema em que a ave permanece confinada durante todo o período de criação, vem dando espaço ao sistema semiintensivo. Este sistema, informalmente conhecido como "tipo caipira", permite que as aves tenham livre acesso à áreas de pastejo, resultando em diferenças particulares na qualidade da carne das mesmas quando comparada com a das aves criadas confinadas.

Conforme Silva \& Nakano (1998), essas diferenças ocorrem devido principalmente à ingestão, pela ave, de pasto, verduras, insetos, larvas, minhocas, etc., que são abundantes no sistema semi-intensivo de criação. Sendo assim, consumidores mais exigentes preferem a carne de aves criadas semi-confinadas por possuir um sabor mais "natural" do que a carne de aves criadas totalmente confinadas.

Segundo Blokhuis et al. (1998 e 2000), a produção e qualidade dos produtos estão ligadas ao bem-estar do animal portanto, os sistemas de produção devem evoluir para atender as necessidades dos consumidores (Verbeke, et al., 2000 e Vercoe et al., 2000).

O bem-estar do animal e sua saúde devem ser considerados em um sistema de criação (Bockisch et al., 1999). De acordo com Dawkins (1999), planteis em que animais não ficam doentes, não morrem, não sofrem injúrias ou deformações, provavelmente não têm seu bem-estar afetado, mas é necessária a avaliação do ambiente de criação para garantir a economicidade de um sistema de criação (Fuchs, 2001). Infelizmente, não há consenso de como se medir e/ou avaliar na prática o bem-estar do animal (Sundrum, 2001), o que torna necessária a realização de estudos que avaliem o animal e seu bem-estar em diferentes ambientes de criação (Fraser, 2001). As condições ambientais afetam diretamente o comportamento animal. A temperatura, umidade 
relativa e radiação solar são importantes indicadores da qualidade do ambiente para o animal (Bockisch et al., 1999), por serem agentes estressores (Furlan, et al., 1999).

A procura por indicadores que avaliem o bem-estar animal tem sido alvo de várias pesquisas (Appleby et al., 1992). O aumento da discussão a respeito de bemestar animal tem incentivado pesquisas, com financiamento pela indústria e governo, com o intuito de inovar e resolver problemas da criação ligados ao bem-estar (Blokhuis et al., 2000).

As condições ambientais são importantes para a criação, mas é essencial a utilização de linhagens especializadas e adaptadas ao sistema de criação, pois, somente assim as aves expressarão todo seu potencial, resultando em maior produtividade e rentabilidade para o produtor (Zuanon et al., 1998). Sendo assim, durante o desenvolvimento de linhagens em programas de melhoramento, é necessário que as características de interesse selecionadas sejam testadas, já que por meios destes testes obtêm-se informações sobre o desempenho das linhagens, indicando assim seu potencial e sua adaptabilidade aos sistemas de criação (Abreu et al., 1996).

A seleção genética para determinado ambiente resulta em beneficios para a criação (Ferrante et al., 2001 e Marin et al., 2001), mas é necessária a utilização de uma estratégia de seleção apropriada, que permita a redução do estresse e melhore o bem-estar e a produtividade das aves (Ferrante et al., 2001; Jones \& Mills, 1999; Marin et al., 2001 e Mills \& Faure, 2000).

Sendo assim, objetivou-se neste trabalho a avaliação da adaptação de linhagens de galinhas para corte ao sistema semi-intensivo de criação, através de parâmetros ambientais e comportamentais. 


\subsection{Material e Métodos}

Os materiais genéticos utilizados foram quatro linhagens de galinhas para corte, sendo duas experimentais (Caipirinha, de crescimento lento e 7P, de crescimento rápido e portadora do gene Naked Neck - Na), em desenvolvimento no Departamento de Genética - ESALQ/USP e duas comerciais ( $\mathrm{C} 1$, de crescimento lento e portadora do gene $\mathrm{Na}$ e $\mathrm{C} 2$, de crescimento rápido).

Os pintos de um dia, obtidos no incubatório experimental do Departamento de Genética - ESALQ/USP, foram vacinados ao nascer contra a doença de Marek e alojados, sem separação de sexo, em 16 boxes experimentais. Cada box possuía $4,5 \mathrm{~m}^{2}$ de área interna (abrigo), com acesso à área de pastejo de $35 \mathrm{~m}^{2}$. Utilizaram-se quatro boxes por linhagem, com uma lotação de 35 pintos/box.

$\mathrm{Na}$ primeira semana foram utilizadas lâmpadas incandescentes (150 Watts), na proporção de uma/box, para aquecimento das aves. Até o sétimo dia foram utilizados bebedouros do tipo pressão e comedouros tubulares infantis, na proporção de dois equipamentos de cada tipo por box. A partir do oitavo dia, a água passou a ser fornecida em bebedouros do tipo pendular e a ração em comedouros tubulares tipo adulto, tendo-se utilizado um equipamento de cada tipo por box. Ração e água foram fornecidas à vontade durante todo o período de criação, que se estendeu até 75 dias de idade. Na Tabela 1 encontram-se os tipos de ração utilizados, com as porcentagens dos ingredientes das mesmas. As aves receberam também vacinação contra as doenças de Newcastle e Gumboro na água de bebida, aos 7 e 21 dias de idade, conforme recomendação do fabricante das vacinas. 
Tabela 1. Composição das rações (\%) utilizadas em cada fase do período de criação e níveis de proteína e energia nessas rações.

\begin{tabular}{lcc}
\hline \multicolumn{1}{c}{ Ingredientes } & $\begin{array}{c}\text { Ração Inicial } \\
(0-21 \text { dias })\end{array}$ & $\begin{array}{c}\text { Ração de Engorda } \\
(22-75 \text { dias })\end{array}$ \\
\hline Milho & 60,75 & 68,00 \\
Soja & 31,25 & 24,00 \\
Farelo de Trigo & 2,5 & 2,0 \\
Óleo de Soja & 0,5 & 1,0 \\
Premix de Vitaminas e Minerais & 5,0 & 5,0 \\
Proteína Bruta (\%) & 20,0 & 17,0 \\
Energia Metabolizável (kcal/kg) & 3.000 & 3.150 \\
\hline
\end{tabular}

Quando as aves atingiram 21 dias de idade, o acesso ao pasto foi aberto, permitindo a livre passagem das aves de cada box para o respectivo pasto. Após um período de 14 dias de adaptação, iniciou-se o período de monitoramento, que se desenvolveu entre 35 e 75 dias de idade, durante o qual foram coletados dados de duas em duas horas, a partir de $8 \mathrm{~h}$ até $20 \mathrm{~h}$ (horário de Brasília), da quantidade de aves presentes no pasto, para se obter a taxa média diária de permanência no pasto (TX).

Paralelamente, coletou-se dados de termômetros de globo negro, que medem a sensação térmica da ave em função do ambiente, e de higrômetros que medem a umidade relativa, presentes no interior dos boxes e no pasto, além da porcentagem de sombra no pasto.

O delineamento experimental foi em blocos casualizados, com quatro repetições, sendo que cada bloco era composto por quatro boxes, um de cada linhagem. 


\subsection{Resultados e Discussão}

Na Tabela 2 estão apresentadas as taxas médias de permanência no pasto das quatro linhagens avaliadas. A linhagem C2 apresentou menor taxa de permanência (6,6 aves/dia), durante o período experimental, diferindo estatisticamente das outras três linhagens, sendo que a linhagem $\mathrm{Cl}$ foi a que apresentou maior taxa média de permanência no pasto, 9,6 aves/dia.

Tabela 2. Taxas médias de permanência no pasto (TX) das linhagens, obtidas no período de 35 a 75 dias de idade.

\begin{tabular}{cc}
\hline Linhagens & $\mathrm{TX}\left(\mathrm{n}^{\mathrm{o}}\right.$ de aves/dia $)$ \\
\hline $\mathrm{C} 1$ & $9,6 \mathrm{a}$ \\
$7 \mathrm{P}$ & $8,4 \mathrm{a}$ \\
Caipirinha & $8,3 \mathrm{a}$ \\
$\mathrm{C} 2$ & $6,6 \mathrm{~b}$ \\
\hline
\end{tabular}

Médias seguidas de diferentes letras diferem estatisticamente pelo teste de Tukey $(\mathrm{p}<0,05)$

As médias da variação diária dos valores da taxa de permanência das linhagens e das temperaturas verificadas no pasto são representadas graficamente na Figura 1. Pode-se observar que quanto maior a temperatura no pasto, menor foi a quantidade de aves presentes no pasto. A maior temperatura no pasto $\left(52^{\circ} \mathrm{C}\right)$ ocorreu às $12 \mathrm{~h}$, enquanto que a menor $\left(28^{\circ} \mathrm{C}\right)$ ocorreu às $20 \mathrm{~h}$; as maiores taxas de permanência no pasto ocorreram no início da manhã e final da tarde e as menores no período entre $12 \mathrm{~h}$ e $14 \mathrm{~h}$, para todas as linhagens. 


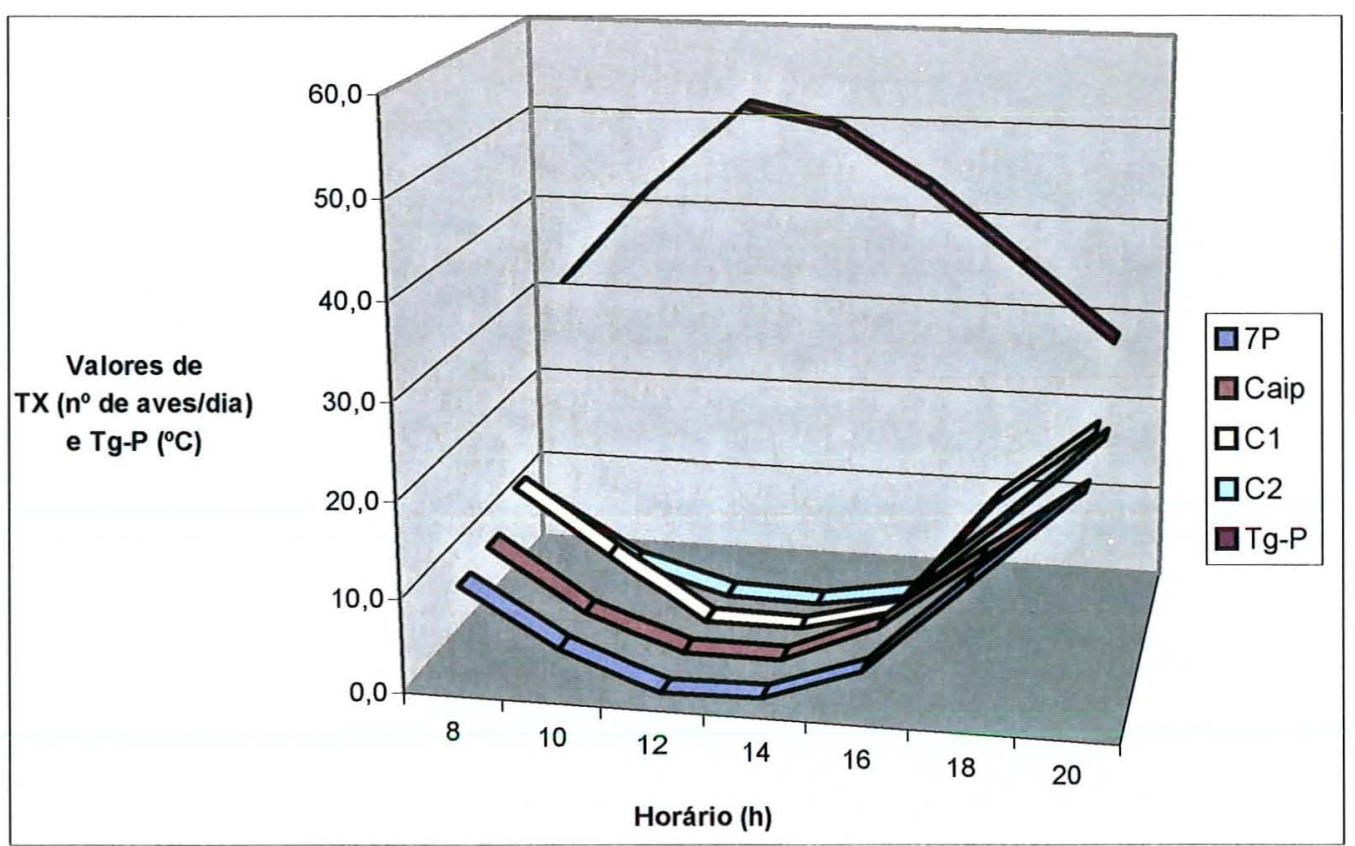

Figura 1 - Médias diárias da taxa de permanência no pasto (TX) das linhagens, em função das temperaturas médias verificadas no pasto (Tg-P), em diferentes horários.

As temperaturas médias de globo negro no pasto ao longo do período de acompanhamento ( $8 \mathrm{~h}$ às $20 \mathrm{~h}$ ) sempre foram maiores do que as temperaturas médias de globo negro no interior dos boxes (Figuras 1 e 2). Quando consideradas as temperaturas de globo negro nos boxes (Figura 2), a taxa de permanência de aves no pasto foi menor no período em que ocorreu maior temperatura no interior do box $\left(40,8^{\circ} \mathrm{C} /\right.$ às $\left.12 \mathrm{~h}\right)$, ou seja, mesmo quando a temperatura no box foi alta as aves permaneceram em seu interior e não no pasto. A hipótese mais provável desse fato ter ocorrido é que no período entre $12 \mathrm{~h}$ e $14 \mathrm{~h}$, em que ocorreram as menores taxas de permanência no pasto para todas as linhagens, a temperatura do pasto foi maior do que a do box e a porcentagem de sombra no pasto foi a menor (Figura 3). Portanto, a alta incidência de radiação solar e a maior temperatura do pasto fizeram com que as aves se abrigassem nos boxes. 


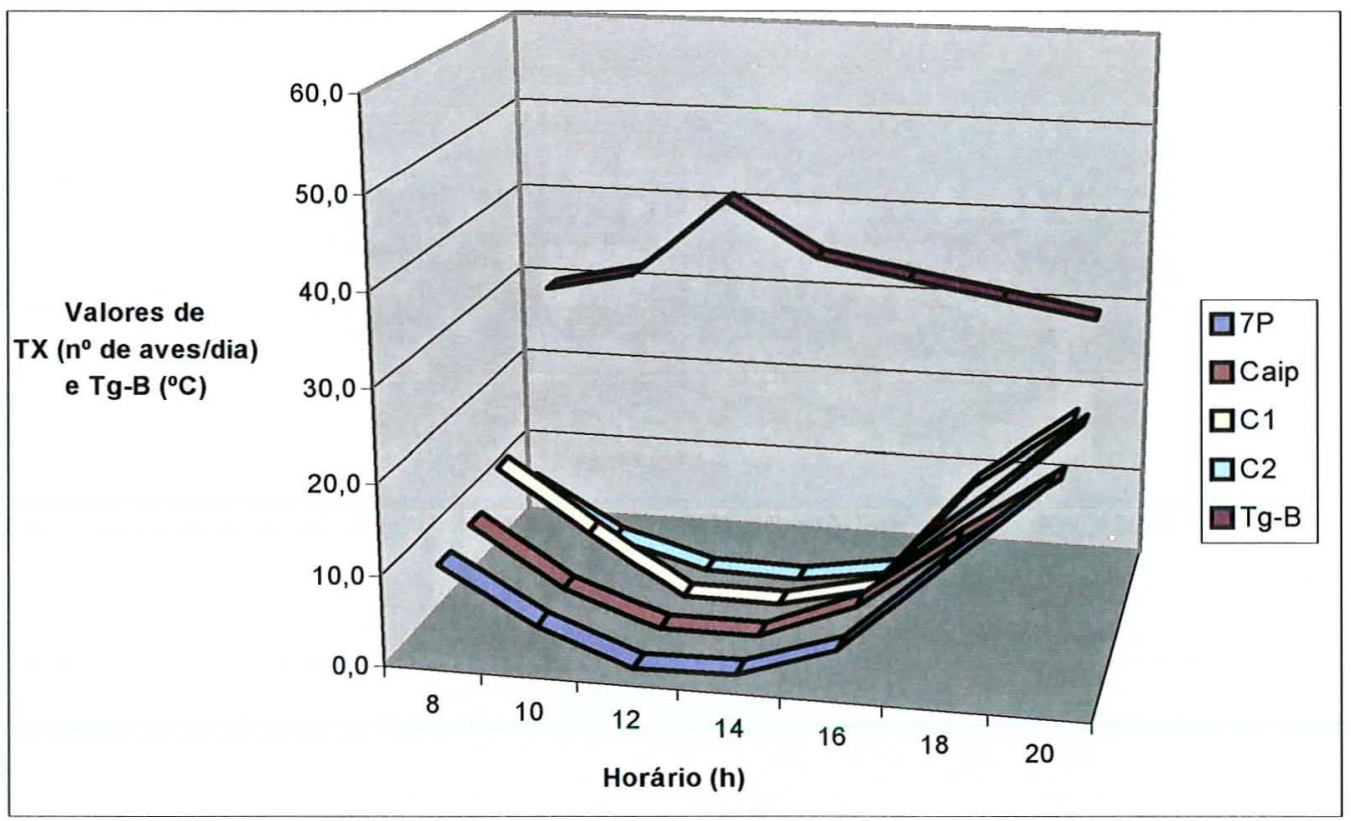

Figura 2 - Médias diárias da taxa de permanência no pasto (TX) das linhagens, em função das temperaturas médias verificadas no interior dos boxes (Tg-B), em diferentes horários.

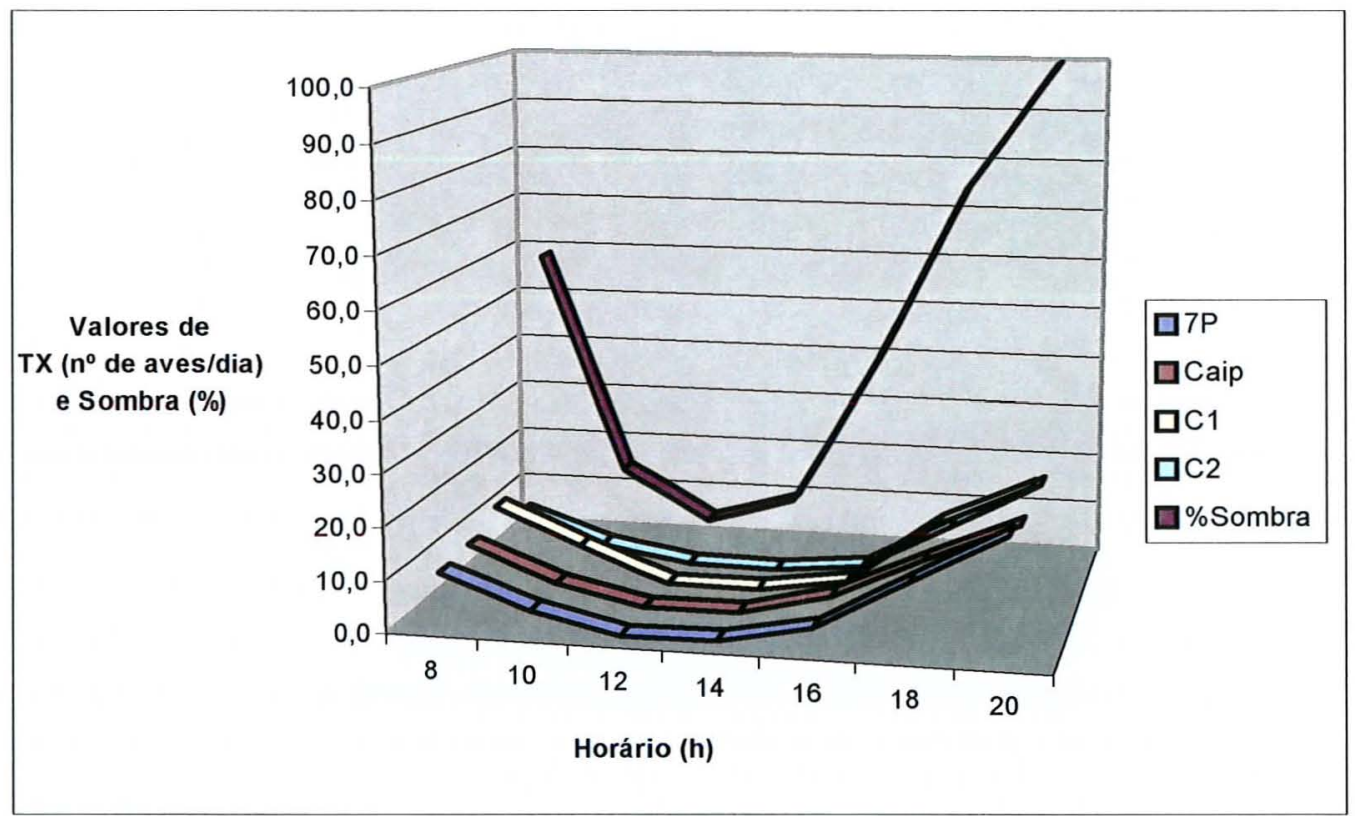

Figura 3 - Médias diárias da taxa de permanência no pasto (TX) das linhagens, em função da porcentagem de sombra no pasto, em diferentes horários. 
Os valores médios da umidade relativa do ar no pasto e no interior dos boxes estão apresentados nas Figuras 4 e 5, respectivamente. A umidade relativa (\%) foi maior no pasto do que no interior dos boxes em todas as leituras entre $8 \mathrm{~h}$ e $20 \mathrm{~h}$, ao longo do dia, sendo que os valores máximos ocorreram no início da manhã ( $8 \mathrm{~h}$ ), tanto no pasto como nos boxes ( $86 \%$ no pasto e $75,8 \%$ no interior dos boxes). Pode-se observar que as aves tenderam a permanecer no pasto nos horários em que a umidade relativa no pasto e nos boxes foram as maiores, ou seja, no início da manhã e no final da tarde.

Segundo Craig \& Muir (1996) e Ferrante et al. (2001), o comportamento do animal está ligado ao ambiente de criação e a melhora deste ambiente pode beneficiar a criação (Jones et al., 2000 e Von Borell \& Van den Weghe, 1999). A taxa de permanência das aves no pasto, ou seja, o comportamento das aves, foi afetado pelos fatores ambientais avaliados, demonstrando a importância de estudo dos fatores ambientais que podem além de afetar o comportamento, afetar também o bem-estar do animal.

As linhagens Caipirinha, 7P e $\mathrm{Cl}$ mostraram-se mais adaptadas ao sistema de criação semi-intensivo pois se comportaram da maneira esperada, ou seja, permaneceram no pasto com maior freqüência quando comparadas com a linhagem C2. Duncan (1998) cita que o comportamento pode ser utilizado como parâmetro para avaliar a qualidade do bem-estar das aves; portanto, uma vez que o ambiente de criação proporcionou condições mais adequadas ao comportamento natural das aves, pode-se concluir que o bem-estar destas não foi afetado pelo sistema de criação.

De acordo com Sundrum (2001), o aumento da área de locomoção do animal pode afetar sua saúde e seu bem-estar. Uma vez que as aves permaneçam com maior freqüência no pasto, se locomovem mais, tendo seu bem-estar melhorado. 


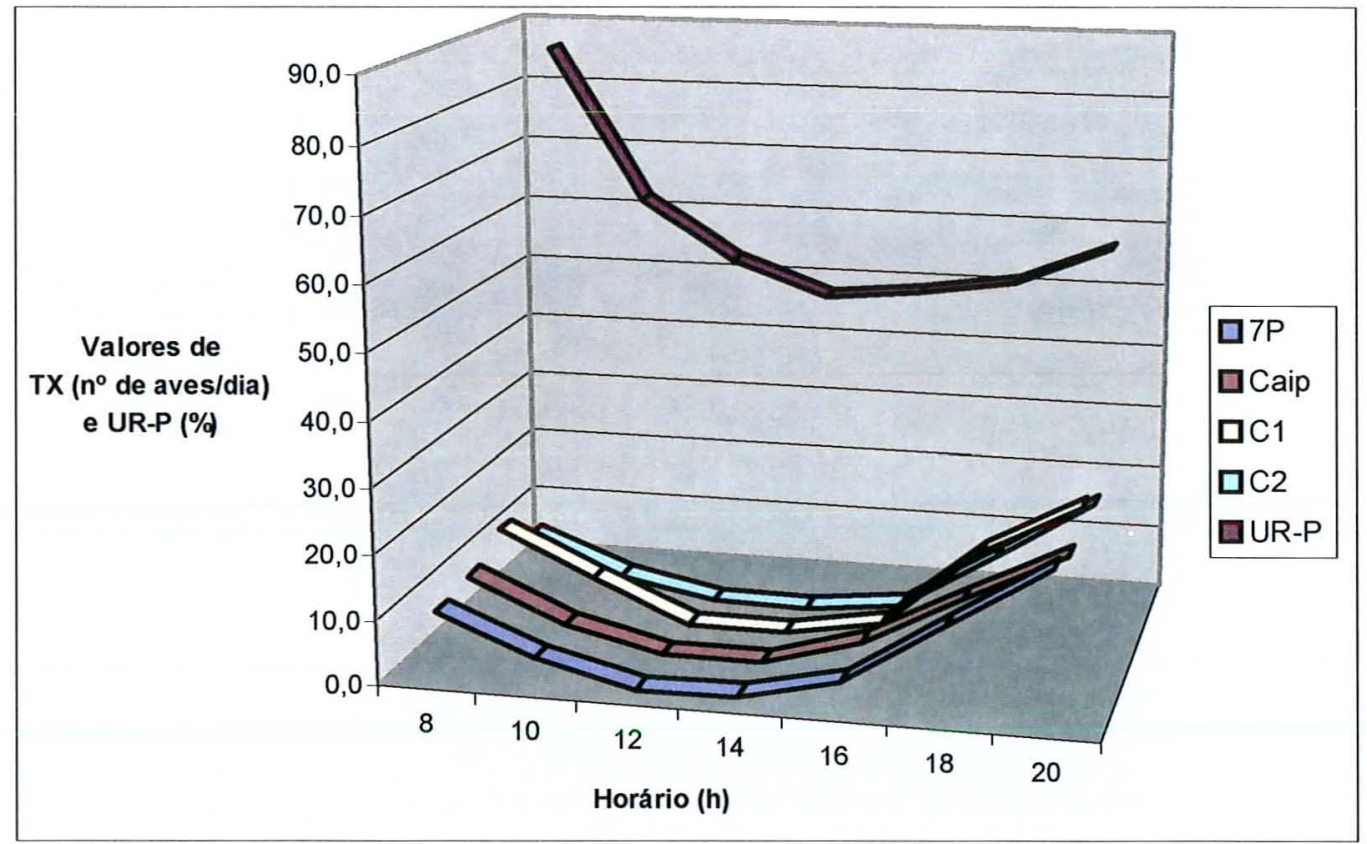

Figura 4 - Médias diárias da taxa de permanência no pasto (TX), em função da umidade relativa no pasto (UR-P), em diferentes horários.

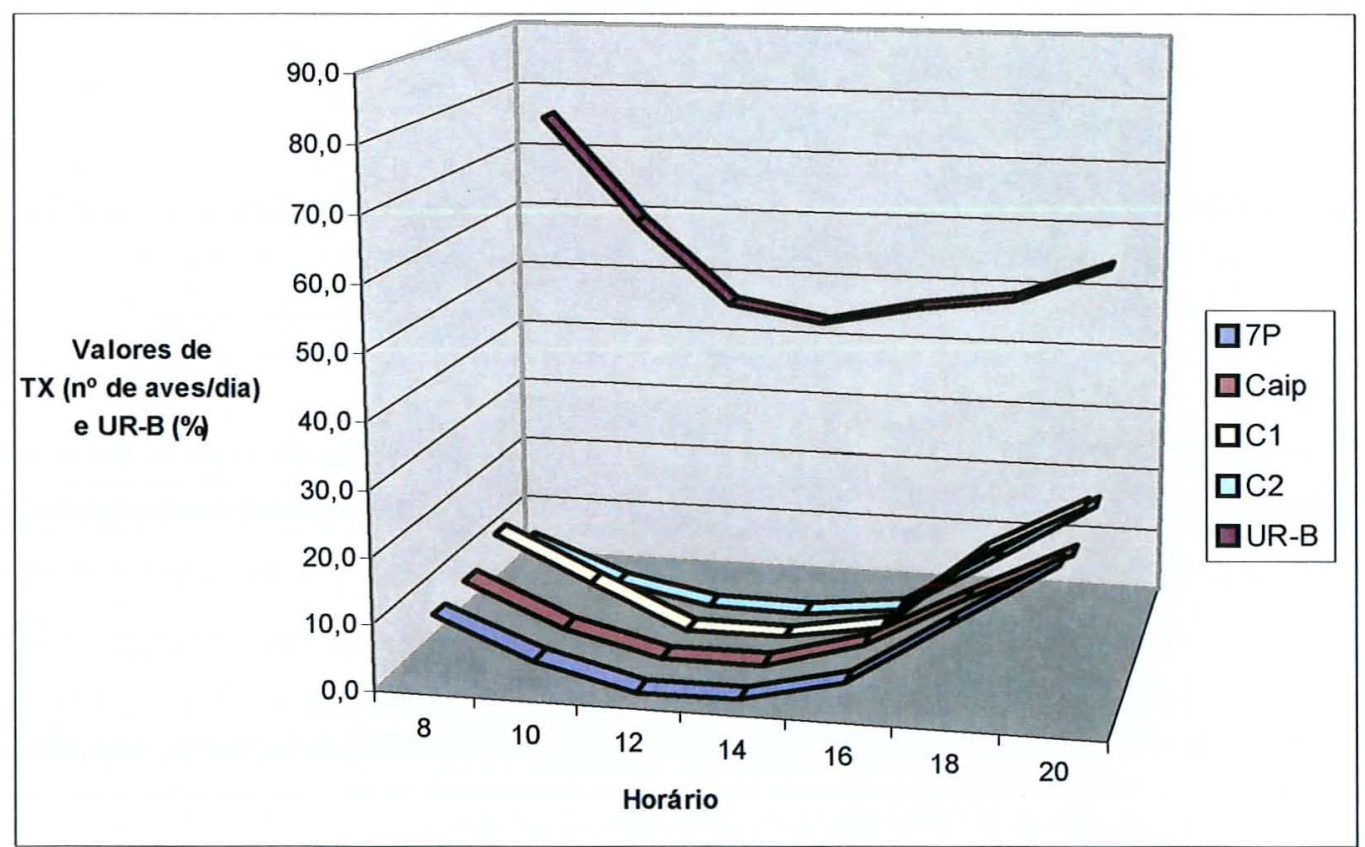

Figura 5 - Médias diárias da taxa de permanência no pasto (TX), em função da umidade relativa no interior dos boxes (UR-B), em diferentes horários. 


\subsection{Conclusões}

A adaptação das linhagens pode ser avaliada utilizando-se parâmetros ambientais e comportamentais. O sistema de criação semi-intensivo influenciou o comportamento das aves, afetando positivamente o bem-estar das aves, mostrando-se adequado quando utilizado. 


\section{INFLUÊNCIA DO SISTEMA DE CRIAÇÃO SOBRE CARACTERÍSTICAS FISIOLÓGICAS E PESO CORPORAL DE LINHAGENS DE GALINHAS PARA CORTE}

\section{Resumo}

A criação em ambientes que diminuam as condições de estresse preservando o conforto $\mathrm{e}$ bem-estar das aves, pode aumentar a produtividade $\mathrm{e}$ rentabilidade da avicultura. A utilização de sistemas de criação alternativos, como o semi-intensivo, que permite que as aves tenham acesso à áreas de pastejo, pode evitar respostas fisiológicas e comportamentais que causam sérios problemas para a saúde e bem-estar das aves. Realizou-se este trabalho com o intuito de avaliar a influência do sistema de criação (intensivo e semi-intensivo) na condição fisiológica (temperatura retal, taxa respiratória e hematócrito), assim como no desempenho (peso corporal) de linhagens especializadas de galinhas para corte, nas idades de 45, 55, 65 e 75 dias. Verificaram-se diferenças significativas nos parâmetros fisiológicos $(\mathrm{p}<0,01)$ e peso corporal $(p<0,05)$ das aves nos dois sistemas. Na criação semi-intensiva obtiveram-se menores valores para temperatura retal, taxa respiratória e hematócrito e valores superiores de peso corporal. Concluiu-se que a criação semi-intensiva proporcionou condições que aumentaram o bem-estar das aves, tendo influenciado positivamente a condição fisiológica e o desempenho das linhagens avaliadas. 


\section{Summary}

The breeding in environments which reduce stressing conditions and provide comfort and welfare for the chicken may increase the productivity and profitability of poultry production. The use of alternative breeding systems, such as semi-intensive which allows chickens to have access to pasture areas, can avoid behavioural and physiological responses that cause serious problems to the chicken's health and welfare. This work was carried out in order to evaluate the influence of breeding systems (intensive or semi-intensive) on physiological conditions (rectal temperature, respiratory rate and hematocrit) as well as on the performance (body weight) of meat-type chicken lines, in the ages of 45, 55, 65 and 75 days old. Significant differences were found in physiological factors $(p<0,01)$ and body weight $(p<0,05)$ of chicken in both systems. In the semi-intensive breeding were found lower values for rectal temperature, respiratory rate and hematocrit, and higher values for body weight. It was concluded that the semi-intensive breeding provided conditions that increased chicken's welfare having positively influenced physiological conditions and performance of the evaluated lines.

\subsection{Introdução}

As condições climáticas de regiões tropicais (alta temperatura e umidade) têm interferido negativamente na produtividade e na qualidade da criação de frangos de corte devido, principalmente, ao aumento da mortalidade, diminuição da ingestão de água e de alimento e, consequentemente, piora na conversão alimentar (Silva \& Silva, 1998). Condições ambientais estressantes podem influenciar a condição fisiológica das aves (Furlan, et al., 1999), resultando em perdas de produtividade.

Estudos têm sido realizados com o intuito de diminuir o efeito negativo de ambientes com alta temperatura e umidade na produção de frangos de corte (Cahaner \& Leenstra, 1992; Leenstra \& Cahaner, 1992 e Yalçin et al., 1997). 
Trabalhos relatam que frangos de corte portadores do gene $\mathrm{Na}$ (Pescoço Pelado), em função de uma redução de até $40 \%$ na plumagem, são capazes de dissipar mais calor que aves não portadoras, diminuindo assim a influência negativa da temperatura durante o período de criação (Yahav et al., 1998 e Yalçin et al., 1997) e melhorando os índices zootécnicos (Eberhart \& Washburn, 1993 e Yalçin et al., 1997).

Eberhart \& Washburn (1993), Mazzi (1998) e Yahav et al. (1998) constataram maiores índices de temperatura retal média em aves com empenamento normal do que em aves portadoras do gene $\mathrm{Na}$, quando expostas ao estresse térmico. Segundo Eberhart \& Washburn (1993) uma maior temperatura corporal sob condições de estresse térmico está associada à menor resistência ao calor. Mazzi (1998) e Yahav et al. (1998) relatam que a menor temperatura retal apresentada pela linhagem de pescoço pelado, durante períodos de estresse, é resultante de um melhor mecanismo de termorregulação da temperatura corporal apresentado por essas aves.

Quando as aves são submetidas a estresse térmico, além de ocorrer aumento da temperatura retal, ocorre também aumento da ofegação para estimular a perda evaporativa de calor, como mecanismo para manter o equilíbrio térmico corporal (Mazzi, 1998). Bottje \& Harrison (1985) e Furlan et al. (1999) também associam o aumento da taxa respiratória com o resfriamento corporal por evaporação, ou seja, em situações de hipertermia, as aves aumentam a taxa respiratória para elevar a evaporação $\mathrm{e}$, consequentemente, resfriar melhor o corpo.

A criação intensiva em ambientes estressantes, aliada à seleção fenotípica para o desenvolvimento de linhagens de frangos de corte mais produtivas, ou seja, com elevada taxa de ganho de peso, maior rendimento de carcaça e alta eficiência alimentar, resultaram no aparecimento de síndromes fisiológicas como estresse calórico, morte súbita e ascite (Sanchez et al., 2000). 
Macari et al. (1994) e Rosário et al. (2000) realizaram estudos sobre a incidência da ascite e verificaram que a ave, na tentativa de suprir a elevada demanda de oxigênio para as diferentes partes do corpo devido ao alto metabolismo, aciona mecanismos homeostáticos, aumentando a circulação sangüínea e a produção de hemácias. A necessidade de aumento da circulação para suprir a demanda de sangue arterial para todo o organismo resulta na hipertrofia ventricular direita (Rosário et al., 2000), e o aumento do número de hemácias resulta no aumento do valor hematócrito (Macari et al., 1994).

Quando existe um desbalanço entre a demanda e o suprimento de oxigênio para atender a alta velocidade metabólica, o quadro ascítico se instala, sendo que os sintomas externos são acúmulo de fluido ascítico e diminuição na taxa de crescimento (Decuypere et al., 2000).

As perdas mundiais devido à ascite totalizam aproximadamente um bilhão de dólares por ano (Maxwell \& Robertson, 1997) e por isso, parâmetros indiretos, tais como, contagem de hemácias, hematócrito e viscosidade sangüínea vêm sendo recomendados para o monitoramento dos plantéis que são utilizados na seleção de aves resistentes à ascite (Fedde \& Wideman Júnior, 1996; Maxwell et al.,1992 e Shlosberg et al.,1992).

O hematócrito é uma metodologia indireta utilizada no monitoramento da ascite em frangos de corte, que mensura a porcentagem de hemácias do sangue, sendo que aves com valores elevados apresentam maior suscetibilidade (Shlosberg et al., 1992).

Segundo Shlosberg et al (1992), aves ascíticas apresentam maiores valores de hematócrito. Maxwell et al. (1992) relataram que para frangos de corte o

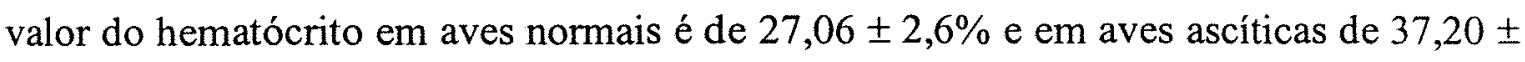
$10,6 \%$. Isto reforça a hipótese de Shlosberg et al. (1992) de que o hematócrito pode ser 
um parâmetro indireto para o monitoramento da síndrome ascítica e, consequentemente, pode ser utilizado na seleção de genótipos resistentes à síndrome ascítica.

Mudanças no ambiente de criação que diminuam as condições de estresse, podem melhorar o conforto do animal, seu bem-estar e, consequentemente, a produção (Blokhuis et al., 1998). Estudos que vêm sendo realizados na área de genética tentam desenvolver aves com melhor adaptabilidade, visando a melhora dos índices zootécnicos da criação (Silva et al., 2001). Sendo assim, objetivou-se a análise da influência do sistema de criação (intensivo e semi-intensivo) na condição fisiológica e desempenho das linhagens especializadas envolvidas na pesquisa e, consequentemente, na melhora das condições de criação, visando o bem-estar das aves.

\subsection{Material e Métodos}

Foram utilizadas quatro linhagens de galinhas para de corte, sendo duas experimentais (Caipirinha, de crescimento lento e 7P, de crescimento rápido e portadora do gene Naked Neck - Na), em desenvolvimento no Departamento de Genética ESALQ/USP e duas comercias ( $\mathrm{C} 1$, de crescimento lento e portadora do gene $\mathrm{Na}$ e $\mathrm{C} 2$, de crescimento rápido).

Os pintos de um dia, obtidos no incubatório experimental do Departamento de Genética - ESALQ/USP, foram vacinados contra a doença de Marek, e a seguir alojados, sem separação de sexo, em 8 boxes experimentais, sendo dois boxes por linhagem, com uma lotação de 35 pintos/box. Cada box possuía $4,5 \mathrm{~m}^{2}$ de área interna, sendo que um box de cada linhagem possuía acesso a uma área para pastejo com $35 \mathrm{~m}^{2}$.

$\mathrm{Na}$ primeira semana foram utilizadas lâmpadas incandescentes (150 Watts) para aquecimento das aves, uma para cada box. Até o sétimo dia foram utilizados bebedouros do tipo pressão e comedouros tubulares infantis, na proporção de dois 
equipamentos de cada tipo por box. A partir do oitavo dia, a água passou a ser fornecida em bebedouros do tipo pendular e a ração em comedouros tubulares para aves adultas, na quantidade de um equipamento de cada tipo por box. Ração e água foram distribuídas à vontade para as aves durante todo o período de criação que se estendeu até 75 dias de idade.

Na Tabela 3 encontram-se os tipos de ração utilizados, bem como as porcentagens de ingredientes nas mesmas. As aves receberam vacinação contra as doenças de Newcastle e Gumboro na água de bebida, aos 7 e 21 dias de idade, conforme recomendação do fabricante das vacinas.

Tabela 3. Composição das rações (\%) utilizadas em cada fase do período de criação e níveis de proteína e energia nessas rações.

\begin{tabular}{lcc}
\hline \multicolumn{1}{c}{ Ingredientes } & $\begin{array}{c}\text { Ração Inicial } \\
(0-21 \text { dias })\end{array}$ & $\begin{array}{c}\text { Ração de Engorda } \\
(22-75 \text { dias })\end{array}$ \\
\hline Milho & 60,75 & 68,00 \\
Soja & 31,25 & 24,00 \\
Farelo de Trigo & 2,5 & 2,0 \\
Óleo de Soja & 0,5 & 1,0 \\
Premix de Vitaminas e Minerais & 5,0 & 5,0 \\
Proteína Bruta (\%) & 20,0 & 17,0 \\
Energia Metabolizável (kcal/kg) & 3.000 & 3.150 \\
\hline
\end{tabular}

Quando as aves atingiram 21 dias de idade, o acesso ao pasto foi aberto, permitindo a livre passagem das aves de cada box para o respectivo pasto. O período de coleta de dados desenvolveu-se entre 45 e 75 dias de idade, utilizando-se as idades de $45,55,65$ e 75 dias para monitoramento de temperatura retal, taxa respiratória, hematócrito e peso corporal. Todos os parâmetros foram obtidos, escolhendo-se ao acaso cinco aves de cada box, quando a temperatura ambiente era de $32^{\circ} \mathrm{C}$. Vale ressaltar que 
esta temperatura ambiente foi escolhida com o intuito de se avaliar as linhagens em condições de estresse térmico.

O peso corporal foi obtido através de pesagem em balança tipo dinamômetro, com capacidade até $5 \mathrm{~kg}$ e precisão de $20 \mathrm{~g}$. Os índices de temperatura retal foram obtidos de acordo com Silva et al. (2001), introduzindo-se o sensor de um teletermômetro (Max-Min Thermo Hygro), na cloaca das aves. A taxa respiratória foi obtida através de avaliação visual, levando-se em consideração o número de vezes que as aves inspiraram ar por minuto de tempo. Já o hematócrito foi determinado através da técnica do micro-hematócrito, descrita por Rosário et al. (2000), coletando-se amostras de sangue de 5 aves de cada linhagem em microtubos capilares, e a seguir centrifugando-se os mesmos a $12.000 \mathrm{x}$ g, em centrífuga IEC para microtubos capilares, modelo MB, utilizando-se rotor do tipo Fixed Angle com capacidade para 24 microtubos. A determinação dos valores de hematócrito foi feita através de leitura com o auxílio de cartão de leitura (FANEM Ltda) com escalas padronizadas.

O delineamento experimental foi em faixa com parcelas sub-divididas, sendo as linhagens alocadas nas parcelas e o sistema de criação (confinado ou não) nas sub-parcelas. A análise de variância das características zootécnicas estudadas foi processada pelo programa de computação SAS (1985), no procedimento GLM (General Linear Models), e a comparação de médias foi realizada utilizando-se o teste de Tukey $(p<0,05)$. O modelo matemático correspondente foi:

$Y i j k=u+L i+e i+S j+e j+(L x S) i j+e i j+I k+(I \times L) i k+e i j k$

em que,

Yijk = valor observado da ave da linhagem $i$, no sistema de criação $j$, na idade $\mathrm{k}$;

$$
\mathrm{u}=\text { média geral; }
$$




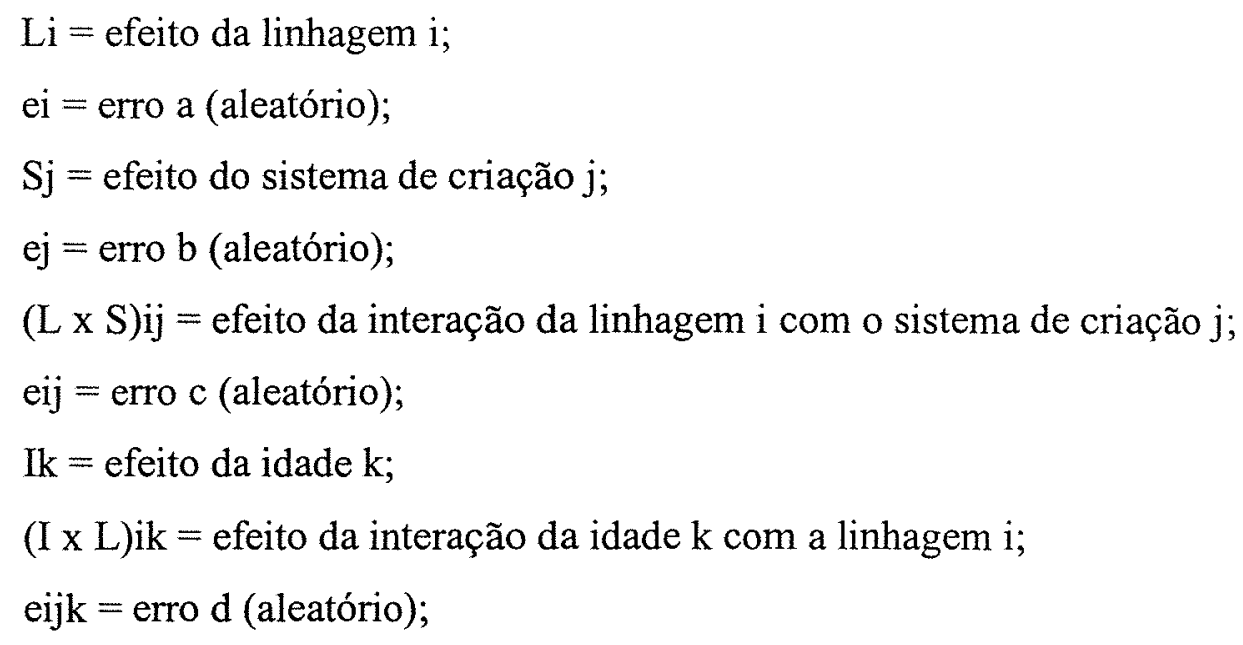

\subsection{Resultados e Discussão}

Através da análise de variância (Tabela 4) dos resultados observados, detectaram-se diferenças significativas nos valores de temperatura retal, taxa respiratória, hematócrito e peso corporal, nas comparações entre linhagens, sistemas de criação e idade das aves. A variação da característica hematócrito das linhagens foi diferenciada nos dois sistemas. A temperatura retal e o peso corporal das linhagens também mostraram variação diferenciada nas idades estudadas.

Os valores médios da temperatura retal, taxa respiratória, hematócrito e peso corporal das linhagens, sistemas de criação e idades estão apresentadas nas Tabelas 5, 6 e 7, respectivamente. A linhagem $\mathrm{C} 2$ apresentou maiores valores para todos os parâmetros avaliados, enquanto que a linhagem $\mathrm{Cl}$ apresentou os menores valores (Tabela 5), com diferenças significativas entre as quatro linhagens para essas características.

Segundo Eberhart \& Washburn (1993), Mazzi (1998) e Yahav et al. (1998), aves que apresentam maiores índices de temperatura retal e de taxa respiratória em condições de estresse térmico são menos resistentes ao calor. Essa situação pode ser agravada com o aumento da idade e do peso corporal da ave, mas pode ser amenizada se 
a ave for portadora do gene $\mathrm{Na}$ (Silva et al., 2001). Os resultados obtidos concordam com os desses autores. A linhagem C2, de empenamento normal e maior peso corporal, apresentou temperatura retal e taxa respiratória superiores as das outras três linhagens de menores pesos corporais, sendo duas portadoras do gene $\mathrm{Na}$.

Os valores de hematócrito apresentados pelas linhagens estudadas, considerados intermediários segundo Maxwell et al. (1992), diferiram estatisticamente pelo teste de Tukey $(\mathrm{p}<0,01)$. A interação significativa encontrada entre os fatores linhagem e sistema de criação para o parâmetro valor de hematócrito (Tabela 4), demonstrou haver respostas diferenciadas das linhagens. Vale ressaltar que aves com valores de hematócrito elevados apresentam maior suscetibilidade à síndrome ascítica (Shlosberg et al., 1992). Sendo assim, a utilização de linhagens que apresentem baixos valores de hematócrito e de um sistema de criação adequado, poderiam minimizar as conseqüências dessa síndrome.

Tabela 4. Análise de variância dos parâmetros estudados.

\begin{tabular}{|c|c|c|c|c|c|}
\hline \multirow[b]{2}{*}{$\mathrm{FV}$} & \multirow[b]{2}{*}{ GL } & \multicolumn{4}{|c|}{ Quadrado Médio } \\
\hline & & $\begin{array}{c}\text { Temperatura } \\
\text { Retal }\end{array}$ & $\begin{array}{c}\text { Taxa } \\
\text { Respiratória }\end{array}$ & Hematócrito & Peso Corporal \\
\hline Linhagem (L) & 3 & $1,602 * *$ & $4058,291 * *$ & $30,458 * *$ & $6421627,290^{* *}$ \\
\hline erro a & 9 & 0,004 & 3,402 & 0,0358 & 36760,625 \\
\hline Sistema (S) & 1 & $2,304 * *$ & $366,025 * *$ & $20,808 * *$ & $317730,625 *$ \\
\hline erro b & 3 & 0,002 & 0,558 & 0,132 & 23840,625 \\
\hline $\mathrm{L} \times \mathrm{S}$ & 3 & $0,004 \mathrm{~ns}$ & $10,291 \mathrm{~ns}$ & $1,497 *$ & $78677,292 \mathrm{~ns}$ \\
\hline erro $\mathrm{c}$ & 32 & 0,003 & 5,675 & 0,470 & 393974,38 \\
\hline Idade (I) & 3 & $0,776 * *$ & $603,491 * *$ & $12,425 * *$ & $12358537,290 * *$ \\
\hline$I \times L$ & 9 & $0,008 * *$ & $1,980 \mathrm{~ns}$ & $0,094 \mathrm{~ns}$ & $100863,290 * *$ \\
\hline Resíduo & 96 & 0,003 & 3,941 & 0,644 & 25958,540 \\
\hline CV (\%) & & 11,91 & 18,85 & 20,65 & 7,62 \\
\hline
\end{tabular}


Tabela 5. Comparação entre as médias gerais das linhagens para os parâmetros temperatura retal $\left({ }^{\circ} \mathrm{C}\right)$, taxa respiratória $\left(\mathrm{n}^{\circ}\right.$ de vezes/min), hematócrito $(\%)$ e peso corporal $(\mathrm{g})$.

\begin{tabular}{ccccc}
\hline Linhagens & $\begin{array}{c}\text { Temperatura } \\
\text { Retal }\end{array}$ & $\begin{array}{c}\text { Taxa } \\
\text { Respiratória }\end{array}$ & Hematócrito & Peso Corporal \\
\hline C2 & $42,23 \mathrm{a}$ & $115,10 \mathrm{a}$ & $31,11 \mathrm{a}$ & $2490,00 \mathrm{a}$ \\
$7 \mathrm{P}$ & $41,99 \mathrm{~b}$ & $112,40 \mathrm{~b}$ & $30,59 \mathrm{~b}$ & $2411,75 \mathrm{a}$ \\
Caipirinha & $41,95 \mathrm{c}$ & $99,70 \mathrm{c}$ & $29,91 \mathrm{c}$ & $1895,50 \mathrm{~b}$ \\
C1 & $41,75 \mathrm{~d}$ & $94,05 \mathrm{~d}$ & $29,09 \mathrm{~d}$ & $1662,50 \mathrm{c}$ \\
\hline
\end{tabular}

Médias seguidas de letras diferentes na mesma coluna diferem estatisticamente pelo teste de Tukey $(\mathrm{p}<0,01)$

$\mathrm{Na}$ comparação entre as médias gerais verificadas nos dois sistemas de criação (Tabela 6) foram observados menores valores de temperatura retal, taxa respiratória e hematócrito e maior valor de peso corporal em aves criadas no sistema semi-intensivo, o que demonstra a influência do sistema de criação nesses parâmetros.

Tabela 6. Comparação entre as médias gerais verificadas nos dois sistemas de criação para os parâmetros temperatura retal $\left({ }^{\circ} \mathrm{C}\right)$, taxa respiratória $\left(\mathrm{n}^{\circ} \mathrm{de}\right.$ vezes/min), hematócrito (\%) e peso corporal (g) das aves.

\begin{tabular}{ccccc}
\hline Sistemas & $\begin{array}{c}\text { Temperatura } \\
\text { Retal }^{1}\end{array}$ & $\begin{array}{c}\text { Taxa } \\
\text { Respiratória }\end{array}$ & Hematócrito $^{1}$ & Peso Corporal $^{2}$ \\
\hline Intensivo & $42,10 \mathrm{a}$ & $106,82 \mathrm{a}$ & $30,57 \mathrm{a}$ & $2070,38 \mathrm{a}$ \\
Semi-Intensivo & $41,86 \mathrm{~b}$ & $103,80 \mathrm{~b}$ & $29,82 \mathrm{~b}$ & $2159,50 \mathrm{~b}$ \\
\hline
\end{tabular}

Médias seguidas de letras diferentes na mesma coluna diferem estatisticamente pelo teste de Tukey $\left({ }^{1} \mathrm{p}<0,01 \mathrm{e}^{2} \mathrm{p}<0,05\right)$ 
A idade influenciou os valores dos parâmetros avaliados (Tabela 7), ou seja, quanto mais velhas as aves, maiores valores de temperatura retal, taxa respiratória, hematócrito e peso corporal foram apresentados, resultando em diferenças significativas entre as idades. A interação significativa entre os fatores idade e linhagem (Tabela 4), demonstra haver também respostas diferenciadas das linhagens para esses parâmetros nas idades avaliadas.

Tabela 7. Comparação entre as médias gerais das aves nas idades avaliadas para os parâmetros temperatura retal $\left({ }^{\circ} \mathrm{C}\right)$, taxa respiratória $\left(\mathrm{n}^{\circ}\right.$ de vezes $\left./ \mathrm{min}\right)$, hematócrito (\%) e peso corporal $(\mathrm{g})$.

\begin{tabular}{ccccc}
\hline Idades (dias) & $\begin{array}{c}\text { Temperatura } \\
\text { Retal }\end{array}$ & $\begin{array}{c}\text { Taxa } \\
\text { Respiratória }\end{array}$ & Hematócrito & Peso Corporal \\
\hline 75 & $42,11 \mathrm{a}$ & $110,00 \mathrm{a}$ & $30,89 \mathrm{a}$ & $2753,00 \mathrm{a}$ \\
65 & $42,04 \mathrm{~b}$ & $106,50 \mathrm{~b}$ & $30,31 \mathrm{~b}$ & $2355,25 \mathrm{~b}$ \\
55 & $41,98 \mathrm{c}$ & $103,80 \mathrm{c}$ & $29,91 \mathrm{bc}$ & $1871,00 \mathrm{c}$ \\
45 & $41,78 \mathrm{~d}$ & $100,90 \mathrm{~d}$ & $29,60 \mathrm{c}$ & $1480,50 \mathrm{~d}$ \\
\hline
\end{tabular}

Médias seguidas de letras diferentes na mesma coluna diferem estatisticamente pelo teste de Tukey $(\mathrm{p}<0,01)$

\subsection{Conclusões}

Os sistemas de criação empregados diferenciaram a condição fisiológica e o desempenho das quatro linhagens testadas. A criação semi-intensiva proporcionou condições que aumentaram o bem-estar das aves, tendo influenciado positivamente suas condições fisiológicas e desempenhos. 


\section{CARACTERIZAÇÃO MOLECULAR DE LINHAGENS DE GALINHAS PARA CORTE CRIADAS EM SISTEMA SEMI-INTENSIVO}

\section{Resumo}

A utilização de marcadores moleculares, aliada à avaliação fenotípica, vem facilitando a seleção de materiais genéticos em programas de melhoramento de aves. Realizou-se o presente trabalho com a intenção de se avaliar o emprego da técnica de RAPD (Random Amplified Polymorphic DNA) na obtenção de polimorfismos para caracterização (análise de similaridade genética) de quatro linhagens de galinhas para corte (duas experimentais - Caipirinha e $7 \mathrm{P}$ e duas comerciais - $\mathrm{Cl}$ e $\mathrm{C} 2$ ), destinas à criação em sistema semi-intensivo. A linhagem Caipirinha apresentou maior similaridade com a linhagem $7 \mathrm{P}$ e menor similaridade com a linhagem $\mathrm{C}$. Na análise de agrupamento foram encontrados 2 grupos distintos, um formado pelas linhagens $\mathrm{C} 1$ e $\mathrm{C} 2$ e outro pelas linhagens Caipirinha e 7P. A técnica de RAPD, através da obtenção de polimorfismos adequados, permitiu a caracterização das linhagens avaliadas, demonstrando sua viabilidade de utilização em programas de melhoramento genético de aves.

\section{Summary}

The use of molecular markers together with fenotypical evaluation, have made easier the genetic selection in poultry breeding programmes. This work was carried out in order to evaluate the use of RAPD (Random Amplified Polymorphic DNA) technique in the obtention of polymorphisms for characterization (analysis of 
genetic similarity) of four meat-type chicken lines (two experimental - Caipirinha and $7 \mathrm{P}$ and two commercial - $\mathrm{C} 1$ and $\mathrm{C} 2$ ) bred in the semi-intensive system. The Caipirinha line presented similarity higher with $7 \mathrm{P}$ line and ower with $\mathrm{C} 1$ line. In the group analysis two distinct groups were found: one formed by $\mathrm{C} 1$ and $\mathrm{C} 2$ lines and other by Caipirinha and 7P lines. The RAPD technique, through the obtention of adequate polymorphisms, allowed the characterization of the evaluated lines showing its viability in poultry breeding programmes.

\subsection{Introdução}

O melhoramento genético tem contribuído de forma significativa para o aumento de produção, para a melhora da qualidade da carne e diminuição do custo de produção da avicultura brasileira (Abreu et al., 1996). Segundo Ciocca et al. (1995), estudos e linhas de pesquisas referentes à avaliação de animais e ao desenvolvimento de um sistema adequado às condições brasileiras, não têm ainda resultados suficientes para cobrir todos os aspectos zootécnicos essenciais, o que dificulta a manutenção de um nível de produção adequado. Lopes \& Quaas (1997) constataram que um grande obstáculo ao desenvolvimento de materiais genéticos e de programas de melhoramento genético de aves é o estabelecimento de critérios eficientes de seleção.

As análises de polimorfismos de DNA, através da avaliação de fragmentos de restrição ou de outras técnicas, aliadas aos critérios fenotípicos normalmente utilizados para seleção, vêm se tornando uma ferramenta poderosa em programas de melhoramento, proporcionando novas possibilidades para a seleção dos animais (Coelho, 1997; Dodgson et al., 1997; Mitra et al., 1999 e Silva et al., 1999).

Estudos têm mostrado o grande potencial do uso da técnica de RAPD (Random Amplified Polymorphic DNA) na caracterização de linhagens, no melhoramento genético e na seleção de animais por permitir a análise de polimorfismos 
e a identificação de marcadores moleculares (Chen et al., 1995; Crittenden et al., 1993; Cushwa \& Medrano, 1996; Grupta et al., 1994; Levin et al., 1993 e Silva et al., 1999).

A análise de polimorfismos de DNA através da técnica de RAPD baseiase no princípio de que um oligonucleotídeo ("primer") escolhido ao acaso, submetido à temperaturas cíclicas na presença de uma seqüência de DNA, inicia a amplificação de vários fragmentos de DNA. Assim, os produtos da reação são separados em géis de agarose e visualizados com brometo de etídio (Ferreira \& Grattapaglia, 1995). A origem dos fragmentos que foram amplificados é altamente dependente da seqüência do primer e da seqüência de DNA genômico de cada indivíduo testado (Cushwa \& Medrano, 1996 e Silva et al., 1999).

Plotsky et al. (1995) avaliando a diversidade genética entre e dentro de 13 linhas de aves altamente melhoradas, constataram que dos 14 primers utilizados para obtenção de polimorfismos através da técnica de RAPD, 12 amplificaram pelo menos uma banda. A partir dos resultados encontrados, os autores puderam concluir que a técnica de RAPD mostrou-se um método efetivo para caracterização de linhas de aves.

Smith et al. (1996) realizaram estudo utilizando a técnica de RAPD para analisar a diversidade genética entre e dentro de quatro populações de galinhas e duas populações de perus. No estudo, após testarem 60 primers, verificaram que 42 primers amplificaram pelo menos um fragmento polimórfico nas populações avaliadas, o que permitiu a construção de "Band Sharing" (BS) para avaliação da diversidade genética existente entre e dentro das populações testadas.

Da mesma forma como no estudo realizado por Smith et al. (1996), Burlando et al. (1996) utilizaram a técnica de RAPD apara avaliar a diversidade genética e possíveis rotas de migração de pica-paus na Itália e concluíram, em função dos fragmentos amplificados pelos primers testados, que a técnica pode ser utilizada para tais estudos. 
Dolmatova et al. (2000) demonstraram a viabilidade da utilização da técnica de RAPD na avaliação e seleção de parentais para desenvolvimento de linhagens de patos mais produtivas.

Utilizando a técnica de RAPD, Kumar et al. (2000) constataram que dos três primers testados para avaliar a diversidade genética entre e dentro de linhas de codorna, dois permitiram a obtenção de polimorfismos, confirmando a aplicabilidade da técnica em análise genética.

Sharma et al. (2000) utilizaram a técnica de RAPD na deteç̧ão de polimorfismos entre duas raças de aves. De 30 primers testados, 7 permitiram a obtenção de polimorfismos e, consequentemente, a avaliação de diversidade entre e dentro das duas raças, demonstrando a viabilidade de uso da técnica nesse tipo de estudo.

A utilização de técnicas moleculares para caracterização e seleção de materiais genéticos no que diz respeito à características ligadas à produção é de grande valia, assim como a seleção para características ligadas à adaptação ao ambiente e ao bem-estar, podendo resultar na melhoria do plantel e na diminuição dos custos de produção (Fairfull et al., 1998; Fairfull \& Muir, 1996; Jones \& Hocking, 1999; Muir, 1994; Muir, 1999 e Muir \& Stick, 1998).

\subsection{Material e Métodos}

Com o objetivo de se caracterizar as linhagens de galinhas para corte envolvidas na pesquisa, foram realizadas análises laboratoriais com marcadores moleculares obtidos a partir da técnica de RAPD. A descrição detalhada da metodologia envolvida nesse estudo é apresentada a seguir. 


\subsubsection{Extração de DNA das aves}

Inicialmente coletou-se de cada ave, três bulbos de penas da asa, acondicionando-se posteriormente em microtubos (eppendorf ${ }^{\mathrm{TM}}$ ) com capacidade para 1,5 $\mathrm{mL}$, contendo $1 \mathrm{~mL}$ de etanol e a partir desses bulbos foi extraído DNA.

O DNA foi extraído através do procedimento utilizado por Miyaki (1993), o qual consiste basicamente na lise das células por choque osmótico, desproteinizações sucessivas, finalizando com a precipitação e lavagem do DNA com etanol. A seguir descreve-se com maiores detalhes este procedimento.

Foram adicionados $500 \mu \mathrm{L}$ de TNE $1 \mathrm{X}, 50 \mu \mathrm{L}$ Tris-HCl $1 \mathrm{M}, 24 \mu \mathrm{L}$ de SDS $25 \%$ e $20 \mu \mathrm{L}$ de Proteinase " $\mathrm{K}$ " (10 mg/mL) em um bulbo de pena disposto em microtubo com capacidade para $2,0 \mathrm{~mL}$, incubando-se a seguir, a $55^{\circ} \mathrm{C}$ por quatro horas.

Após o período de incubação foram adicionados $200 \mu \mathrm{L}$ de $\mathrm{NaCl} 5 \mathrm{M}$ e 1,0 $\mathrm{mL}$ de Clorofane, misturando-se a fase aquosa com a fase orgânica até homogeneização completa. Posterior à homogeneização, o material foi centrifugado por 5 minutos a $15.000 \times \mathrm{g}$, em centrífuga BECKMAN, modelo Microfuge $\mathrm{E}$, utilizando-se rotor do tipo Fixed Angle com capacidade para 12 microtubos. Após a centrifugação o sobrenadante foi recuperado cuidadosamente com auxílio de uma pipeta e colocado em microtubo limpo. Foi adicionado 1,0 mL de etanol absoluto, misturando-se por inversão, até o aparecimento de um precipitado branco, o DNA. Após, centrifugou-se por dois minutos a $15.000 \mathrm{x} \mathrm{g}$, descartando-se, posteriormente, o etanol absoluto. $\mathrm{O}$ mesmo procedimento foi realizado utilizando-se $500 \mu \mathrm{L}$ de etanol $70 \%$. Posteriormente as amostras foram colocadas em estufa a $37^{\circ} \mathrm{C}$, para depois de seco o DNA ser ressuspendido em $300 \mu \mathrm{L}$ de água Mili-Q. 
Após a diluição das amostras em $300 \mu \mathrm{L}$ de água Mili-Q, foram adicionados $30 \mu \mathrm{L}$ do estoque de RNAse $\mathrm{A}(1,0 \mathrm{mg} / \mathrm{mL} ; 1: 1)$ em cada amostra e estas colocadas em estufa a $37^{\circ} \mathrm{C}$ por uma hora, para promover a digestão do RNA presente na solução.

\subsubsection{Quantificação do DNA extraído}

Passado o tempo de digestão com RNAse A, foi medida a absorbância do

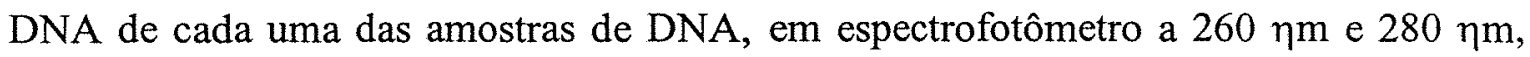
para verificar sua quantidade e qualidade. A concentração de DNA presente em cada amostra foi determinada através das fórmulas (1) e (2) definidas pelo Centro de Mejoramiento de Maíz y Trigo (1995), as quais se baseiam na medida da absorbância em espectrofotômetro a 260 ๆm e na diluição da amostra em água Mili-Q.

$\mathrm{D}=\frac{\mathrm{Q}+\mathrm{X}}{\mathrm{X}}$

em que,

$\mathrm{D}=$ fator de diluição do DNA, para quantificação;

$\mathrm{Q}=$ quantidade de água Mili-Q, em $\mu \mathrm{L}$;

$\mathrm{X}=$ quantidade de DNA ressuspendido em água Mili-Q, em $\mu \mathrm{L}$;

$\mathrm{C}=\frac{\mathrm{A} 260 * 50 * \mathrm{D}}{1000}$

em que,

$\mathrm{C}=$ valor da concentração de DNA, em $\mu \mathrm{g} / \mu \mathrm{L}$;

A 260 = valor da leitura em espectrofotômetro em 260 १m; 
$\mathrm{D}$ = fator de diluição do DNA, para quantificação;

A qualidade do DNA extraído foi avaliada através da relação entre as mediadas de absorbância (260 $\eta \mathrm{m} / 280 \eta \mathrm{m})$ para cada amostra; a integridade do DNA foi avaliada eletroforeticamente em gel de agarose $(0,8 \%$ de agarose em tampão TAE 1X), em corrida de uma hora na velocidade de $50 \mathrm{~mA}$.

\subsubsection{Amplificação do DNA}

Para amplificação foram utilizados "pools" de DNA, onde cada "pool" continha uma mistura homogênea do DNA de cada linhagem. Nas reações de amplificação foram utilizados os seguintes reagentes: $3,0 \mu \mathrm{L}$ de água Mili-Q; $2,5 \mu \mathrm{L}$ de tampão para a enzima Taq DNA polimerase (GIBCO BRL); 7,5 $\mu \mathrm{L}$ de $\mathrm{Mg}^{++} 25 \mathrm{mM}$ (diluído 1:6); 0,2 mM de dNTP mix (dATP, dCTP, dGTP e dTTP - GIBCO BRL); 6,0 $\mu \mathrm{L}$ de oligonucleotídeos iniciadores (primers - Operon Technologies, INC); 1,5 unidades da enzima Taq DNA polimerase (GIBCO BRL), totalizando um volume de $21,3 \mu \mathrm{L}$ de mix por amostra. Este volume de mix foi adicionado à $100 \mathrm{ng}$ de DNA contido em microtubo, sendo um microtubo para cada amostra a ser analisada.

A amplificação do DNA seguiu o protocolo utilizado por Silva et al. (1999) que consistiu em pré-desnaturação feita a $94^{\circ} \mathrm{C}$ por 4 minutos, seguida de 40 ciclos de desnaturação (1 minuto a $\left.94^{\circ} \mathrm{C}\right)$, anelamento $\left(1,5\right.$ minutos a $37^{\circ} \mathrm{C}$ ), polimerização $\left(2,5\right.$ minutos a $\left.72^{\circ} \mathrm{C}\right)$ e 4 minutos finais a $72^{\circ} \mathrm{C}$ em termociclador (PTC100 da M J RESEARCH INC).

\subsubsection{Eletroforese do produto da amplificação}

Os fragmentos amplificados foram separados em géis de agarose $(1,4 \%$ de agarose em tampão TAE 1X), durante três horas de corrida na velocidade de $50 \mathrm{~mA}$. 
Após a eletroforese os géis foram corados com brometo de etídeo $(0,5 \mu \mathrm{g} / \mathrm{mL})$ por 20 minutos, sob agitação lenta e depois lavados em água destilada, permitindo-se assim a visualização de bandas em luz ultra-violeta.

\subsection{Resultados e Discussão}

Os perfis revelados pelos marcadores RAPD, obtidos nas análises laboratoriais, foram avaliados de acordo com a metodologia do "Band Sharing" (BS), descrita por Jeffreys \& Morton (1987), a qual possibilita obter o nível de semelhança ou diferença genética entre dois indivíduos ou grupos. Os BS foram calculados através da fórmula (3), com auxílio do "software" Numerical Taxonomy and Multivariate Analysis System - NTSYS-pc (Rohlf, 1992).

$$
\mathrm{BS}=\frac{2(\mathrm{Nab})}{(\mathrm{Na}+\mathrm{Nb})}
$$

em que,

$\mathrm{Nab}=$ número de bandas coincidentes nos dois perfis;

$\mathrm{Na}=$ número total de bandas do genótipo $\mathrm{A}$;

$\mathrm{Nb}=$ número total de bandas do genótipo $\mathrm{B}$;

Os polimorfismos obtidos com os 7 primers utilizados possibilitaram através da metodologia do "Band Sharing", com base no coeficiente DICE e com o auxílio do "software" NTSYS-pc, obter o nível de semelhança entre as linhagens avaliadas (Tabela 8). As linhagens Caipirinha e 7P apresentaram maior similaridade $(0,925)$ enquanto que, Caipirinha e $\mathrm{C} 1$ apresentaram menor similaridade $(0,800)$. Estes resultados demonstram a viabilidade de utilização da técnica de RAPD nesse tipo de estudo, como descrito por Burlando et al. (1996), Dolmatova et al. (2000), Kumar et al. (2000), Plotsky et al. (1995), Sharma et al. (2000) e Smith et al. (1996). 
Tabela 8. Matrizes de similaridade calculadas com base no coeficiente DICE, a partir dos resultados de amplificação do DNA das linhagens C1 (a), C2 (b), Caipirinha (c) e 7P (d) com os primers B-05 (1), B-08 (2), B-17 (3), B-02 (4), B-03 (5), B-04 (6) e B-07 (7), do Kit B da Operon Technologies, INC.

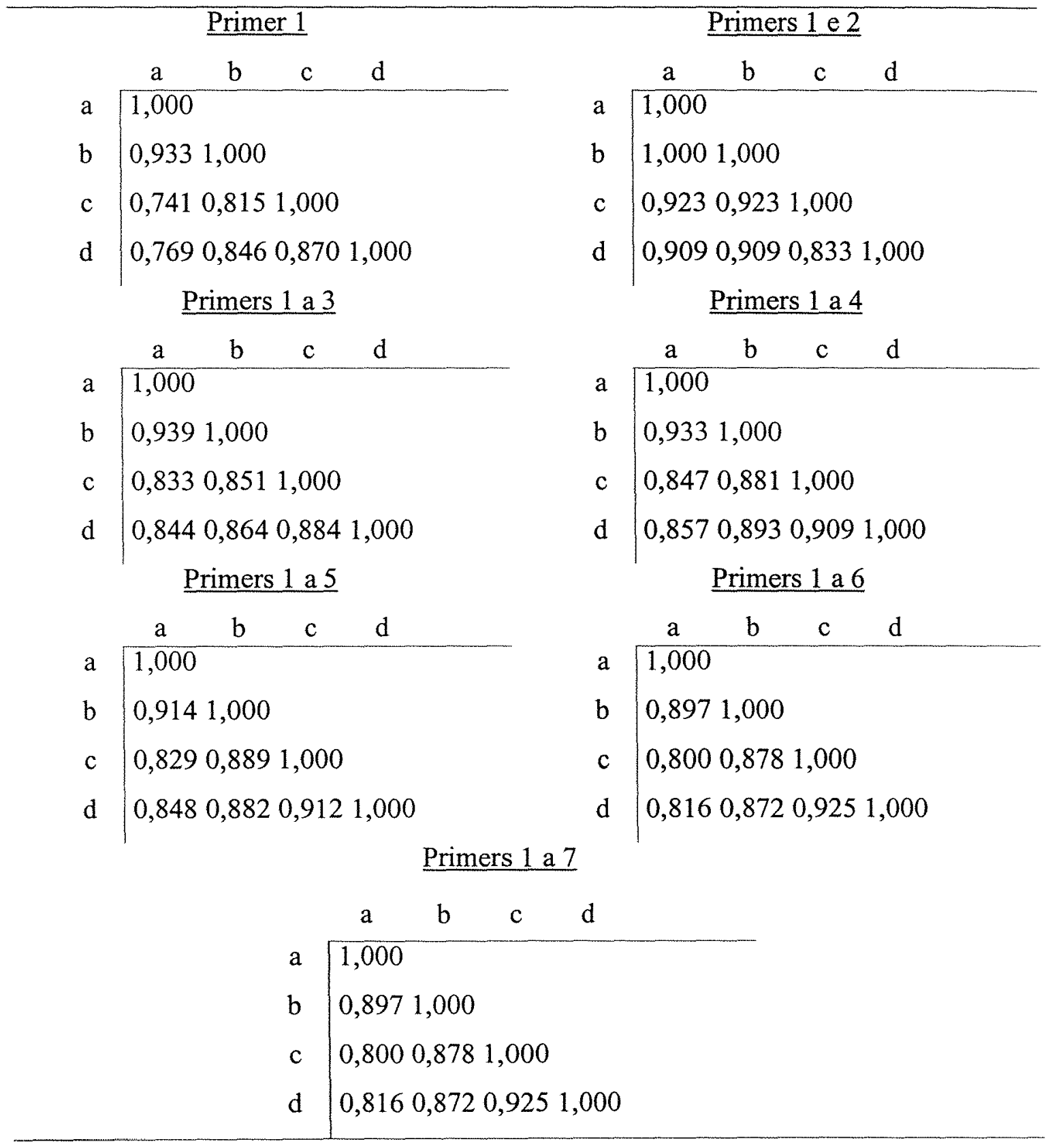


O agrupamento das linhagens foi realizado seguindo-se o método Unweighted Pair-Goup with Arithmetical Averages (UPGMA) de Rohlf (1992). Na análise de agrupamento, foram encontrados dois grupos distintos, um formado pelas linhagens $\mathrm{C} 1$ e $\mathrm{C} 2$ e outro pelas linhagens Caipirinha e 7P (Figuras 6 a 12). Vale ressaltar que houve estabilização dos grupos a partir dos 7 primers utilizados.

BS:

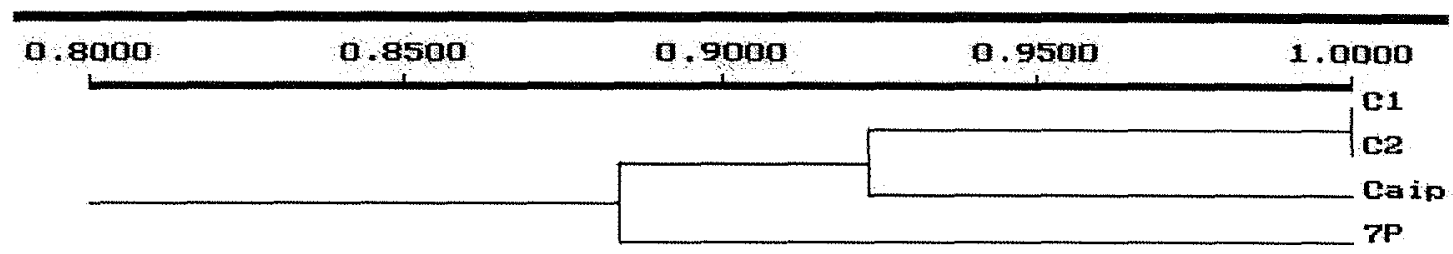

Figura 6 - Análise de agrupamento UPGMA, a partir dos resultados de amplificação do DNA das quatro linhagens com o primer B-05.

BS:

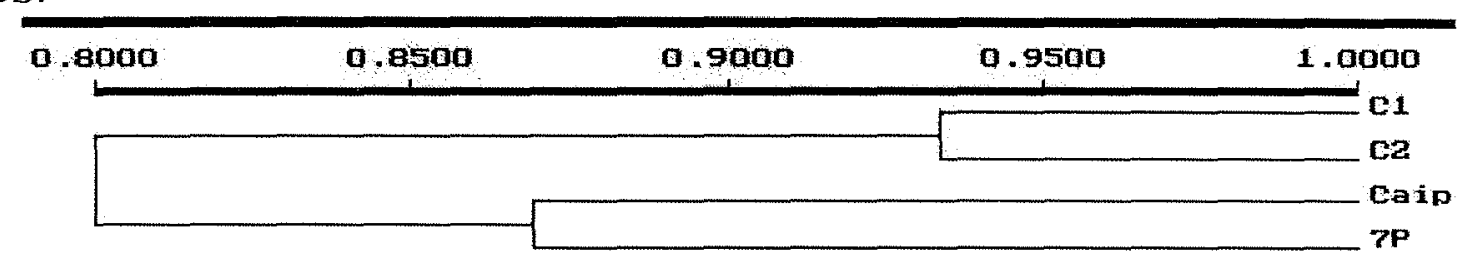

Figura 7 - Análise de agrupamento UPGMA, a partir dos resultados de amplificação do DNA das quatro linhagens com os primers B-05 e B-08.

BS:

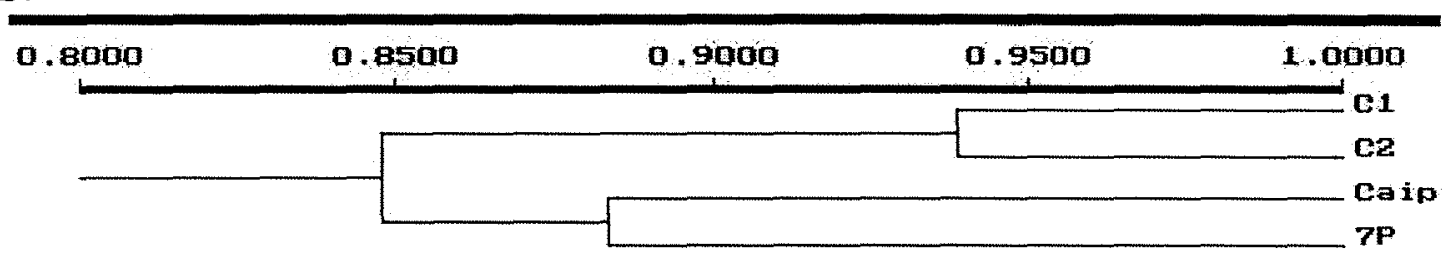

Figura 8 - Análise de agrupamento UPGMA, a partir dos resultados de amplificação do DNA das quatro linhagens com os primers B-05, B-08 e B-17. 
BS:

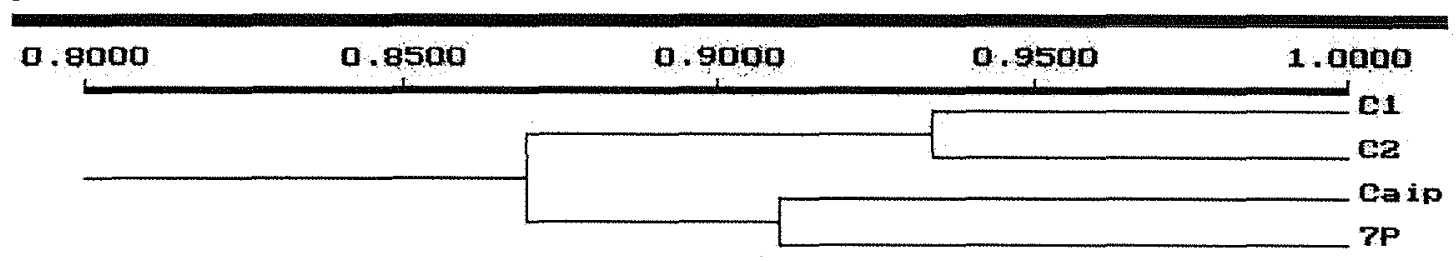

Figura 9 - Análise de agrupamento UPGMA, a partir dos resultados de amplificação do DNA das quatro linhagens com os primers B-05, B-08, B-17 e B-02.

BS:

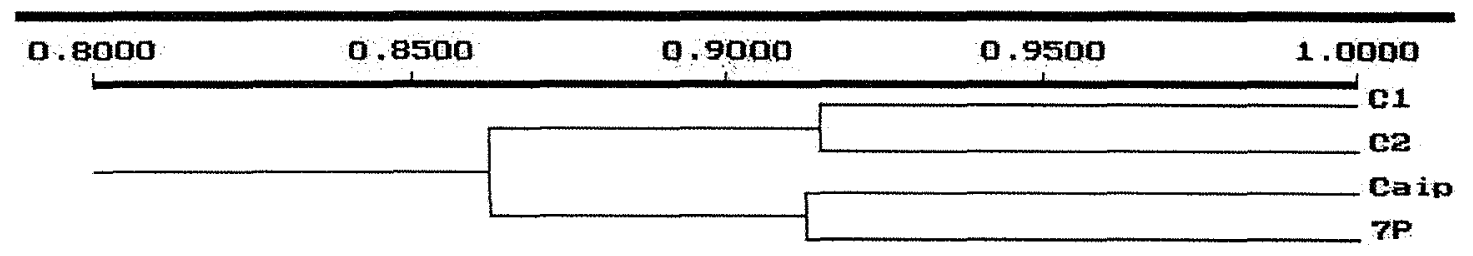

Figura 10 - Análise de agrupamento UPGMA, a partir dos resultados de amplificação do DNA das quatro linhagens com os primers B-05, B-08, B-17, B-02 e B-03.

BS:

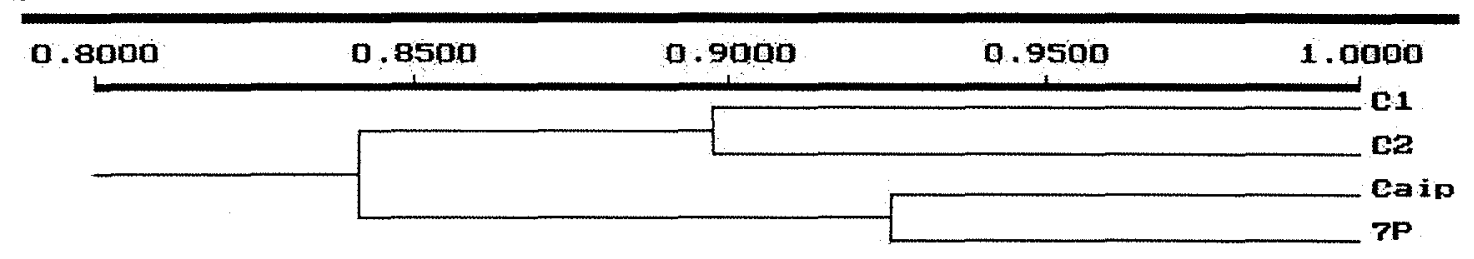

Figura 11 - Análise de agrupamento UPGMA, a partir dos resultados de amplificação do DNA das quatro linhagens com os primers B-05, B-08, B-17, B-02, B-03 e B-04.

BS:

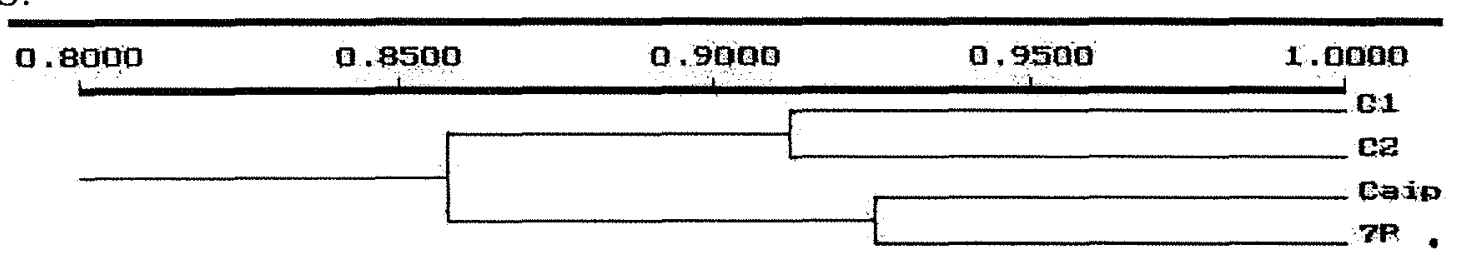

Figura 12 - Análise de agrupamento UPGMA, a partir dos resultados de amplificação do DNA das quatro linhagens com os primers B-05, B-08, B-17, B-02, B-03, B-04 e B-07. 


\subsection{Conclusões}

A caracterização de linhagens especializadas de galinhas para corte demonstrou ser facilitada com a utilização de marcadores moleculares RAPD, como os empregados neste trabalho. Os resultados obtidos permitiram a diferenciação genética das linhagens em estudo, que aliada a seleção fenotípica auxiliará na identificação de materiais genéticos mais adaptados ao sistema semi-intensivo de criação. 


\section{CONCLUSÕES GERAIS}

- Existem respostas diferenciadas no desempenho de linhagens especializadas de galinhas para corte criadas no sistema semi-intensivo.

- Parâmetros ambientais, fenotípicos e comportamentais podem ser utilizados para avaliação da adaptação de linhagens de galinhas para corte ao sistema semi-intensivo de criação.

- O sistema de criação influenciou o comportamento, condição fisiológica e desempenho de galinhas para corte.

- O sistema semi-intensivo proporcionou condições que aumentaram o bem-estar das aves durante a criação.

- A técnica de marcadores moleculares RAPD permitiu a caracterização de linhagens especializadas de galinhas para corte.

- A avaliação fenotípica, aliada à técnicas moleculares pode facilitar a identificação de materiais genéticos mais adaptados ao sistema semi-intensivo de criação. 


\section{REFERÊNCIAS BIBLIOGRÁFICAS}

ABEYESINGHE, S.M.; WATHES, C.M.; NICOL, C.J.; RANDALL, J.M. The aversion of broiler chickens to concurrent vibration and thermal stressors. Applied Animal Behaviour Science, v.73, n.3, p.199-215, 2001.

ABREU, V.M.N.; SILVA, M.A.; TORRES, R.A.; SOARES, P.R.; PANIAGO, M.T.; ABREU, P.G. Características produtivas de linhagens de corte. Revista da Sociedade Brasileira de Zootecnia, v.25, n.1, p.83-91, 1996.

APPLEBY, M.C.; HUGHES, B.O.; ELSON, H.A. Poultry production systems: behaviour, management and welfare. Nottinghan: CAB International, 1992. 238p.

BLOKHUIS, H.J.; EKKEL, E.D.; KORTE, S.M.; HOPSTER, H.; VAN REENEN, C.G. Farm animal welfare research in interaction with society. Veterinary Quarterly, v.22, n.4, p.217-222, 2000.

BLOKHUIS, H.J.; HOPSTER, H.; GEVERINK, N.A.; KORTE, S.M.; VAN REENEN, C.G. Studies of stresse in farm animals. Comparative Haematology International, v.8, n.2, p.94-101, 1998.

BOCKISCH, F.J.; JUNGBLUTH, T.; RUDOVSKY, A. Technical indicators for evaluation of housing systems for cattle, pigs and laying hens relating to animal welfare. Zuchtungskunde, v.71, n.1, p.38-63, 1999. /Resumo em Web of Science, $1999-2000 /$ 
BOTTJE, W.G.; HARRISON. P.C. The effect of tap water, carbonated water, sodium bicarbonate, and calcium chloride on blood acid-base balance in cockerels subjected to heat stress. Poultry Science, v.64, n.1, p.107-113, 1985.

BROOM, D.M. Animal welfare: concepts and measurement. Journal of Animal Science, v.69, n.10, p.4167-4175, 1991.

BURLANDO, B.; ARILLO, A.; SPANO, S.; MACHETTI, M. A study of the variability in populations of the European woodcock (Scolopax rusticola) by random amplifications of polymorphic DNA. Italian Journal of Zoology, v.63, n.1, p.31-36, 1996.

CAHANER, A.; LEENSTRA, F. Effects of high temperature on growth and efficiency of male and female broilers from lines selected for high weight-gain, favorable feed conversion, and high or low fat-content. Poultry Science, v.71, n.8, p.1237-1250, 1992.

CENTRO DE MEJORAMIENTO DE MAIZZ Y TRIGO. Laboratory protocols cimmyt applied molecular genetics laboratory. Mexico, 1995. 66p.

CHEN, X.; MIFLIN, J.K.; ZHANG, P.; BLACKALL, P.J. Development and application of DNA probes and PCR tests for Haemophilus paragallinarum. Avian Diseases, v.40, n.2, p.398-407, 1995.

CIOCCA, M.L.; CARDOSO, S.; FRANZOSI, R. Criação de galinhas em sistemas semi-extensivos. Porto Alegre: Pallotti, 1995. 112p.

COELHO, A.A.D. Análise genética da taxa de crescimento e do desempenho reprodutivo em galinhas para corte. Piracicaba, 1997. 74p. Tese (Doutorado) - Escola Superior de Agricultura “Luiz de Queiroz", Universidade de São Paulo. 
CRAIG, J.V.; MUIR, W.M. Group selection for adaptation to multiple-hen cages: behaviour responses. Poultry Science, v.75, n.10, p.1145-1155, 1996.

CRITTENDEN, L.B.; PROVENCHER, L.; SANTANGELO, L.; LEVIN, I.; ABPLANALP, H.; BRILES, R.W.; BRILES, W.E.; DODGSON, J.B. Characterization of a red jungle fowl by white leghorn backcross reference population for molecular mapping of the chicken genome. Poultry Science, v.72, n.2, p.334-348, 1993.

CUSHWA, W.T.; MEDRANO, J.F. Applications of the random amplified polymorphic DNA (RAPD) assay for genetic analysis of livestock species. Animal Biotchnology, v.7, n.1, p.11-13, 1996.

DAWKINS. M.S. The role of behaviour in the assessment of poultry welfare. Worlds Poultry Science Journal, v.55, n.3, p.295-303, 1999.

DECUYPERE, E.; BUYSE, J.; BUYS, N. Ascites in broiler chickens: exogenous and endogenous structural and functional causal factors. Worlds Poultry Science Journal, v.56, n.4, p.367-377, 2000.

DODGSON, J.B.; CHENG, H.H.; OKIMOTO, R. DNA marker technology: a revolution in animal genetics. Poultry Science, v.76, n.8, p.1108-1114, 1997.

DOLMATOVA, I.Y.; SAITBATALOV, T.F.; GAREEV, F.T. The study of genetic polymorphism using randomly amplified polymorphic DNA in ducks: Estimation of interlinear differences in Peking duck. Russian Journal of Genetics, v.36, n.6. p.661-667, 2000.

DUNCAN, I.J.H. Behavior and behavioral needs. Poultry Science, v.77, n.12, p.1766$1772,1998$. 
EBERHART, D.E.; WASHBURN, K.W. Variation in body-temperature response of naked neck and normally feathered chickens to heat stress. Poultry Science, v.72, n. 8, p.1385-1390, 1993.

FAIRFULL, R.W.; MUIR, W.M. Selection and breeding of laying hens: present and future solution. In: WORLDS POULTRY CONGRESS, 20., New Delhi, 1996. Proceedings. New Delhi: WPSA, 1996. p.395-415.

FAIRFULL, R.W.; McMILLAN, I.; MUIR, W.M. Poultry breeding: progress and prospects for genetic improvement of egg and meat production. In: WORLD CONGRESS ON GENETICS APPLIED TO LIVESTOCK PRODUCTION, 6., Armidale, 1998. Proceedings. Armidale: WAAP, 1998. p.271.

FEDDE, M.R.; WIDEMAN JÚNIOR, R.F. Blood viscosity in broilers: influence on pulmonary hypertension syndrome. Poultry Science, v.75, n.10, p.1261-1267, 1996.

FERRANTE, V.; VERGA, M.; MANGIAGALLI, M.G.; CARENZI, C. Behaviour reactions, semen quality and testosterone levels in cocks: genetic implications. Animal Welfare, v.10, n.3, p.269-279, 2001.

FERREIRA, M.E.; GRATTAPAGLIA, D. Introdução ao uso de marcadores RAPD e RFLP em análise genética. Brasília: EMBRAPA,CENARGEM, 1995. 220p.

FRASER, D. The "new perception" of animal agriculture: legless cows, featherless chickens and a need for genuine analysis. Journal of Animal Science, v.79, n.3, p.634-641, 2001. 
FUCHS, C. Economic efficiency of intensive and extensive animal husbandry. Praktische Tierarzt, v.82, n.8, p.578-580, 2001. /Resumo em Web of Science, 1999 $-2000 /$

FURLAN, R.L.; MACARI, M.; MORAES, V.M.B.; MALHEIROS, R.D.; MALHEIROS, E.B.; SECATO, E.R. Alterações hematológicas e gasométricas em diferentes linhagens de frangos de corte submetidos ao estresse calórico agudo. Revista Brasileira de Ciência Avícola, v.1, n,1, p.77-84, 1999.

GESSULLI, O.P. Avicultura alternativa: sistema "ecologicamente correto" que busca o bem-estar animal e a qualidade do produto final. Porto Feliz: OPG Editores, 1999. $217 \mathrm{p}$.

GRUPTA, M.; CHYI, Y.S.; ROMERO-SEVERSON, J.; OWEN, J.L. Amplification of DNA markers from evolutionarily diverse genomes using single primers of simplesequence repeats. Theoretical and Applied Genetics, v.89, n.7/8, p.998-1006, 1994.

HALL, A.H. The effect of stocking density on the welfare and behaviour of broiler chickens reared commercially. Animal Welfare, v.10. n.1, p.23-40, 2001.

JEFREYS, A.J.; MORTON, D.B. DNA fingerprints of dogs and cats. Animal Genetics, v.18, n.1, p.1-15, 1987.

JONES, R.B.; HOCKING, P. Genetic selection for poultry behaviour: big wolf or friend in need. Animal Welfare, v.8, n.4, p, 343-359, 1999.

JONES, R.B.; MILLS, A.D. Divergent selection for social reinstatement behaviour in Japanese quail: effects on sociality and social discrimination. Poultry and Avian Biology Reviews, v.10, n.4, p.213-223, 1999. /Resumo em Web of Science, 1999 $2000 /$ 
JONES, R.B.; CARMICHAEL, N.L.; RAYNER, E. Pecking preferences and predispositions in domestic chicks: implications for the development of environmental enrichment devices. Applied Animal Behaviour Science, v.69, n.4, p.291-213, 2000.

KUMAR, K.G.; KUMAR, S.; AHLAWAT, S.P.S.; KUMAR, P.; SINGH, R.K.; BISHT, G.S. Randomly amplified polymorphic DNA markers in genetic analysis of relatedness in japanese quail lines. Indian Journal of Animal Science, v.70, n.6. p.604-607, 2000. /Resumo em Web of Science, 1999-2000/

LEENSTRA, F.; CAHANER, A. Effects of low, normal and high temperatures on slaughter yield of broilers from lines selected for high weight-gain, favorable feed conversion, and high or low fat content. Poultry Science, v.71, n.12, p.1994-2006, 1992.

LEVIN, I.; CRITTENDEN, L.B.; DODGSON, J.B. Genetic map of the chicken Z chromosome using Random Amplified Polymorphic DNA (RAPD) markers. Genomics, v.16, n.1, p.224-230, 1993.

LOPES, P.S.; QUAAS, R.L. Estimação de parâmetros genéticos em aves de corte. Revista Brasileira de Zootecnia, v.26, n.6, p.1119-112, 1997.

MACARI, M.; FURLAN, R.L.; GONZALES, E. Fisiologia aviária aplicada a frangos de corte. Jaboticabal: FUNEP, 1994. cap.2, p.12-25: Fisiologia cardiovascular.

MARIN, R.H.; FREYTES, P.; GUZMAN, D.; JONES, R.B. Effects of an acute stressor on fear and on the social reisntatement responses of domestic chicks to cagemates and strangers. Applied Animal Behaviour Science, v.71, n.1, p.57-66, 2001. 
MAXWELL, M.H.; ROBERTSON, G.W. Vision Panorámica de la ascitis en pollos en el mundo: 1996. Industria Avicola, v.44, n.5, p.14-25, 1997.

MAXWELL, M.H.; ROBERTSON, G.W.; McCORQUODALE, C.C. Whole blood and plasma viscosity values in normal and ascitic broiler chickens. British Poultry Science, v.33, n.4, p. 871-877, 1992.

MAZZI, C.M. Análise da expressão da proteína de estresse Hsp70 em frangos de corte portadores do gene "Naked Neck" (pescoço pelado) submetidos a estresse térmico gradativo. Jaboticabal, 1998. 60p. Dissertação (Mestrado) - Faculdade de Ciências Agrárias e Veterinárias, Universidade Estadual Paulista "Julio de Mesquita Filho".

MENDL, M. Performing under pressure: stress and cognitive function. Applied Animal Behaviour Science, v.65, n.3, p.221-244, 1999.

MILLS, A.D.; FAURE, J.M. Ease of capture in lines of Japanese quail (Coturnix japonica) subjected to contrasting selection for fear or sociability. Applied Animal Behaviour Science, v.69, n.2, p.125-134, 2000.

MITRA, A.; YADAV, B.R.; GANAI, N.A.; BALAKRISHNAN, C.R. Molecular markers and their aplications in livestock improvement. Current Science, v.77, n.8, p.1045-1053, 1999.

MIYAKI, C.Y. Utilização de sondas de minisatélite na identificação individual e do parentesco de psitacídeos brasileiros. São Paulo, 1993. 63p. Dissertação (Mestrado) Instituto de Biociências, Universidade de São Paulo.

MORENG, R.E.; AVENS, J.S. Ciência e produção de aves. São Paulo: Roca, 1990. 380 p. 
MUIR, W.M. Poultry improvement: integration of present and new genetics aproaches for layers. In: WORLD CONGRESS ON GENETICS APPLIED TO LIVESTOCK PRODUCTION, 5., Otawa, 1994. Proceedings. Otawa: WAAP, 1994. p.5-12.

MUIR, W.M. Molecular genetics in poultry breeding. In: SIMPÓSIO INTERNACIONAL DE GENÉTICA E MELHORAMENTO ANIMAL, Viçosa, 1999. Anais. Viçosa: UFV, 1999. p.243-267.

MUIR, W.M.; CRAIG, J.V. Improving animal well-being through genetic selection. Poultry Science, v.77, n.12, p.1781-1788, 1998.

MUIR, W.M.; STICK, D. Relative advantage of combining genes with major effects in breeding programs: simulation results. In: WORLD CONGRESS ON GENETICS APPLIED TO LIVESTOCK PRODUCTION, 6., Armidale, 1998. Proceedings. Armidale: WAAP, 1998. p.357-360.

PLOTSKY, Y.; KAISER, M.G.; LAMONT. S.J. Genetic characterization of highly inbred chicken lines by two DNA methods: DNA fingerprinting and polymerase chain reaction using arbitrary primers. Animal Genetics, v.26, n.3, p.163-170, 1995.

PREISINGER, R. Internationalisation of breeding programmes: breeding egg-type chickens for a global market. In: WORLD CONGRESS ON GENETICS APPLIED TO LIVESTOCK PRODUCTION, 6., Armidale, 1998. Proceedings. Armidale: WAAP, 1998. p.135.

ROHLF, F.J. Numerical taxonomy and multivariate analysis system - NTSYS-pc. New York: Exeter Software, 1992. 234p. 
ROSÁRIO, M.F.; SILVA, M.A.N.; MARTINS, E.; SAVINO, V.J.M.; COELHO, A.A.D. Influência do genótipo e do sexo sobre o valor hematócrito em galinhas reprodutoras pesadas. Revista Brasileira de Ciência Avícola, v.2, n.3, p.281-286, 2000 .

SANCHEZ, A.; PLOUZEAU, M.; RAULT, P.; PICARD, M. Muscular growth and cardio-respiratory function in broiler chickens. Productions Animales, v.13, n.1, p. $37-45,2000$.

SAS INSTITUTE. SAS user's guide: statistics. Raleigh, 1985. 956p.

SHARMA, D.; SINGH, D.P.; SINGH, R.V. polymorphism in indigenous poultry germplasm detected through randomly amplified polymorphic DNA. Journal of Applied Animal Research, v.18, n.1, p.115-120, 2000.

SHLOSBERG, A.; ZADIKOV, I.; BENDHEIM, U.; HANDJI, V.; BERMAN, E. The effects of poor ventilation, low tempertaures, type of feed and sex of bird on the development of ascites in broilers: physiological factors. Avian Pathology, v.21, n.3, p.369-382, 1992.

SILVA, I.J.O.; SILVA, M.A.N. Dicas de sucesso: fique por dentro de algumas medidas simples, voltadas à climatização da produção de frangos, que podem garantir o sucesso da criação neste verão. Avicultura Industrial, v.88, n.1059, p.46-47, 1998.

SILVA, M.A.N.; MARTINS, E.; GOMES, L.H.; SAVINO, V.J.M.; COELHO, A.A.D. Introgressão de genes maiores em linhagem de galinhas para corte com a utilização de marcadores moleculares RAPD. Genetics and Molecular Biology, v.22, n.3, p.641, 1999. Suplemento. /Apresentado ao 45. Congresso Nacional de Genética, Gramado, 1999 - Resumo/ 
SILVA, M.A.N.; SILVA, I.J.O.; PIEDADE, S.M.S.; MARTINS, E.; SAVINO, V.J.M.; COELHO, A.A.D. Resistência ao estresse calórico em frangos de corte de pescoço pelado. Revista Brasileira de Ciência Avícola, v.3, n.1, p.27-33, 2001.

SILVA, R.D.M.; NAKANO, M. Sistema Caipira de criação de galinhas. Piracicaba: O Editor, 1998. 110p.

SMITH, E.J.; JONE, C.P.; BARTLETT, J.; NESTOR, K.E. Use randomly amplified polymorphic DNA markers for the genetic analysis of relatedness and diversity in chickens and turkeys. Poultry Science, v.75, n.5, p.579-584, 1996.

SUNDRUM, A. Organic livestock farming - a critical review. Livestock Production Science, v.67, n.3, p.207-215, 2001.

VERBEKE, W.A.J.; VIANE, J. Ethical challenges for livestock production: meeting consumer concerns about meat safety and animal welfare. Journal of Agricultural \& Environmental Ethics, v.12, n.2, p.141-151, 2000. /Resumo em Web of Science, $1999-2000 /$

VERCOE, J.E.; FITZHUGH, H.A.; VON KAUFMANN, R. Livestock productions systems beyond 2000. Asian-Australian Journal of Animal Sciences, v.13, p.411419, 2000. Supplement, S. /Resumo em Web of Science, 1999 - 2000/

VON BORELL, E. Animal welfare as a production factor?. Zuchtungskunde, v.71, n.6, p.473-481, 1999. /Resumo em Web of Science, 1999 - 2000/

VON BORELL, E.; VAN DEN WEGHE, S. Development of criteria for the assessment of housing systems for cattle, pigs and laying hens relating to animal welfare and environmental impact. Zuchtungskunde, v.71, n.1, p.8-16, 1999. /Resumo em Web of Science, $1999-2000 /$ 
YAHA, V.S.; LUGER, D.; CAHANER, A.; DOTAN, M.; RUSAL, M.; HURWITZ, S. Thermoregulation in Naked Neck chickens subjected to different ambient temperatures. British Poultry Science, v.39, n.1, p.133-138, 1998.

YALÇIN, S.; TESTIK, A.; OZKAN, S.; SETTAR, P.; ÇELEN, F.; CAHANER, A. Performance of Naked neck and normal broilers in hot, warm, and temperate climates. Poultry Science, v.76, n.7, p.930-937, 1997.

ZUANON, J.A.S.; FONSECA, J.B.; ROSTAGNO, H.S.; SILVA, M.A. Efeito de promotores de crescimento sobre o desempenho de frangos de corte. Revista Brasileira de Zootecnia, v.27, n.5, p.999-1005, 1998. 
APÊNDICE 
APÊNDICE 1. Composição das soluções utilizadas nas análise laboratoriais de RAPD.

\section{TNE 20X}

- $121,1 \mathrm{~g}$ de Tris Base

- $116,9 \mathrm{~g}$ de $\mathrm{NaCl}$

- $\quad 37,2 \mathrm{~g}$ de EDTA $\left(\mathrm{Na}_{2}\right)$

- Água Mili-Q q.s.p 1,0 L

Obs.: O TNE 1X foi obtido através da diluição do TNE 20X.

\section{Tris $\mathrm{HCl} 1 \mathrm{M}$}

- $121,1 \mathrm{~g}$ de Tris Base

- Água Mili-Q q.s.p 1,0 L (ajustar pH com $\mathrm{HCl}$ para 8,0)

\section{$\underline{\operatorname{SDS} 25 \%}$}

- 250 g de Sodium Dodecyl Sulfate

- Água Mili-Q q.s.p 1,0 L

\section{$\underline{\mathrm{NaCl} 5 \mathrm{M}}$}

- $177,5 \mathrm{~g}$ de $\mathrm{NaCl}$

- Água Mili-Q q.s.p 1,0 L

\section{Clorofane}

- $100 \mathrm{~g}$ de Fenol

- $96 \mathrm{~mL}$ de Clorofórmio

- $4 \mathrm{~mL}$ de Álcool Isoamílico

- $100 \mathrm{mg}$ de 8-Hidroxiquinoleina

- $200 \mathrm{~mL}$ de Tris HCl $1 \mathrm{M} \mathrm{pH} \mathrm{8,0}$ 
Etanol 70\%

- $700 \mathrm{~mL}$ de Estanol absoluto

- Água Mili-Q q.s.p 1,0 L

\section{TAE 50X}

- $242,2 \mathrm{~g}$ de tris Base

- $\quad 37,2$ g de EDTA $\left(\mathrm{Na}_{2}\right)$

- $\quad 57,1 \mathrm{~mL}$ de Ácido Acético

Obs.: O TAE $1 \mathrm{X}$ foi obtido através da diluição do TAE 50X.

Gel de Agarose 0,8\%

- $8 \mathrm{~g}$ de Agarose

- 1,0 L de TAE $1 X$

Gel de Agarose 1,4\%

- $14 \mathrm{~g}$ de Agarose

- $1,0 \mathrm{~L}$ de TAE $1 X$ 